\title{
To insist or to concede? Contractors' behavioural strategies when handling disputed claims
}

DOI:

10.1108/ECAM-05-2018-0219

\section{Document Version}

Accepted author manuscript

Link to publication record in Manchester Research Explorer

\section{Citation for published version (APA):}

Zhang, L., Fenn, F., \& Fu, Y. (2019). To insist or to concede? Contractors' behavioural strategies when handling disputed claims. Engineering Construction and Architectural Management, 26(3), 424-443.

https://doi.org/10.1108/ECAM-05-2018-0219

\section{Published in:}

Engineering Construction and Architectural Management

\section{Citing this paper}

Please note that where the full-text provided on Manchester Research Explorer is the Author Accepted Manuscript or Proof version this may differ from the final Published version. If citing, it is advised that you check and use the publisher's definitive version.

\section{General rights}

Copyright and moral rights for the publications made accessible in the Research Explorer are retained by the authors and/or other copyright owners and it is a condition of accessing publications that users recognise and abide by the legal requirements associated with these rights.

\section{Takedown policy}

If you believe that this document breaches copyright please refer to the University of Manchester's Takedown Procedures [http://man.ac.uk/04Y6Bo] or contact uml.scholarlycommunications@manchester.ac.uk providing relevant details, so we can investigate your claim.

\section{OPEN ACCESS}




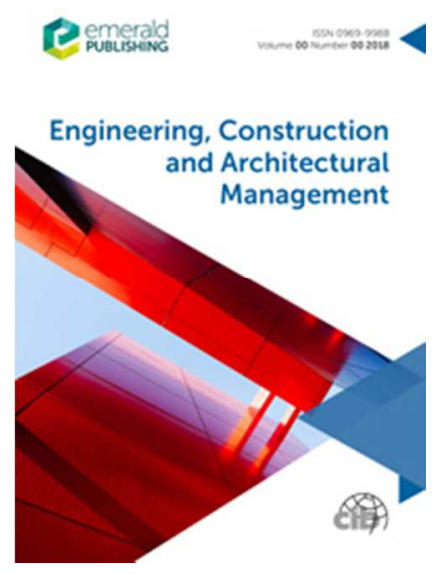

To insist or to concede? Contractors' behavioural strategies when handling disputed claims

\begin{tabular}{|r|l|}
\hline Journal: & Engineering, Construction and Architectural Management \\
\hline Manuscript ID & ECAM-05-2018-0219.R1 \\
\hline Manuscript Type: & Original Article \\
\hline Keywords: & Project Management, Questionaire survey, Construction \\
\hline Abstract: & \\
\hline & \\
\hline
\end{tabular}

SCHOLARONE ${ }^{\text {m }}$

Manuscripts 


\section{To insist or to concede? Contractors' behavioural strategies when handling disputed claims}

Purpose - The purpose is to identify and analyse factors that affect contractors' behavioural strategies in resolving disputed claims.

Design/methodology/approach - Factors were explored by a literature review and an open-ended questionnaire survey. Nine hypotheses involving twelve factors were developed accordingly. Then a structured questionnaire survey was conducted, and 248 valid questionnaires were received from Chinese contractors. Partial least squares structural equation modelling was employed to test the hypotheses.

Findings - Factors that have the largest impacts on the contractual approach, the relational approach regarding obliging and compromising are favorability of evidence, time pressure and reputation, respectively. Unexpected results show that obliging behaviours are negatively correlated with procedural fairness but positively correlated with occurrence time of the dispute.

Research limitations/implications - The results are based on correlation, although the research design improves the internal validity. Furthermore, this study belongs to single-level research. In the future, researchers can conduct multilevel research to enrich theories.

Practical implications - The findings not only enhance practitioners' understanding of the factors influencing contractors' behavioural strategies when dealing with disputed claims, but also offer insights into both parties' ex-ante focus of attention on specific factors to facilitate the subsequent dispute resolution.

Originality/value - This study furnishes a nuanced picture of multiple factors' impacts on contractors' behavioural strategies of claim-related dispute resolution, and thus supplements the relevant construction dispute management literature. From the perspective of contractual governance, it is one of those exploring drivers of contract application in problem situations. It extends the body of knowledge on this topic and hopefully will encourage more research on contractual governance from the reactive perspective.

Keywords Disputed claims, Construction projects, Contractual approach, Relational approach

\section{Introduction}

Claim-related disputes occur when contractors do not accept owners' decisions about claims (Kumaraswamy, 1997). Reasons accounting for disputes include inconsistent viewpoints on rights and responsibilities, incomplete contracts, opportunistic behaviours, etc. (Cheung and Pang, 2013; Awwad et al., 2016). The increasing complexity and uncertainty of construction projects are accompanied by a growth in the number of disputes (Haugen and Singh, 2015). In a construction 
project observed by the authors, a Chinese international contractor negotiated with an owner about a large claim amount due but failed to get an approval. The claim was valid under the contract and would have been awarded at arbitration or litigation. However, the contractor chose to give up mainly because it wished to undertake more projects from this owner in the future. This case motivates the authors' probe into contractors' behavioural strategies when handling disputed claims, i.e. to insist or to concede?

This paper is structured as follows. First, the authors introduce the theoretical background for the study. Knowledge gaps are summarised from two relevant theoretical perspectives, and the research aim is accordingly proposed. Next, research methodology is elaborated to achieve the aim. This is followed by the identification of factors influencing contractors' behavioural strategies of claim-related dispute resolution and the information about the open-ended questionnaire survey. Nine hypotheses involving twelve factors are developed. The authors then describe the structured questionnaire survey and present the results of data analyses. After the data analyses, the findings are discussed. Finally, the authors conclude with theoretical and practical contributions, limitations, and opportunities for future research.

\section{Theoretical Background}

Contractors' behavioural strategies are defined as their planned actions based on goals during the process of claim-related dispute resolution. Behavioural strategies of dispute resolution are classified into a contractual approach and a relational approach (Wang et al., 2016). The contractual approach pertains to heavy reliance upon contracts to claim rights and unilaterally enforce position (Gilliland and Bello, 2002; Wang et al., 2016). Contractors adopting it argue their demands as legitimate to maximise their benefits while portraying owners' position is not supported by contracts (Lumineau and Malhotra, 2011). The relational approach is defined as ignorance of contract contents and reliance on cooperative behaviours in the form of adjusting to the other party' position or finding a mutually acceptable solution (Gilliland and Bello, 2002; Wang et al., 2016). Contractors adopting it set aside the right and make concessions. The degree of concessions varies from obliging (satisfying the other party's concern) to compromising (give-and-take to achieve a mutually acceptable settlement) (Rahim, 2002). These two approaches show contractors' rigid and flexible contract application to solve problems, respectively.

Among construction dispute resolution research, one stream lies in the evaluation and selection of different resolution methods such as negotiation, mediation, dispute adjudication boards (DABs), arbitration, and litigation (e.g., Chan et al., 2006; Gad et al., 2011; Marzouk et al., 2011; Chong and Zin, 2012; Lee et al., 2018). However, a dispute resolution method may reflect contractors' 
different intentions and purposes. For example, contractors may either compete or cooperate during negotiation; arbitration may act as a tool to press for owners' concessions or only a tactic to frighten owners. In contrast, driven by intentions and goals, behavioural strategies can indicate contractors' choices of methods. For instance, the contractual approach implies that contractors will behave competitively during negotiation. If negotiations fail, they tend to refer disputes to the $\mathrm{DAB}$ or even arbitration. Behavioural strategies, therefore, are the core construct in this study.

A few studies investigated the impacts of some factors on parties' behaviours (Yiu et al., 2011; Zhang et al., 2016b; Lu et al., 2017). Nevertheless, their contexts are specific to negotiations. Dispute resolution typically comprises several methods in sequential order. In addition to contending bargaining behaviours, referring disputes to arbitration to strive for benefits also represents rigid contract application in dispute situations. Thus, this study puts focus on the whole dispute resolution process. Additionally, Chan et al. (2010) looked beyond the scope of negotiation and revealed some drivers of investors' strategies, ranging from relational bargaining to legal approach. However, their context is limited to investors' responses to government-initiated concession renegotiations in public-private partnership projects. Hence, there is a paucity of studies identifying factors that affect contractors' behavioural strategies of claim-related dispute resolution.

Contractors' behavioural strategies of dispute resolution embody the degree of their contract application in problem situations, which is a sub-topic of contractual governance. Most contractual governance literature in the construction industry has taken a proactive perspective and focused on the impact of contract design in avoiding problems, including deterring opportunism, promoting cooperation or enhancing performance (e.g., Fu et al., 2015; Lu, P. et al., 2015; Lu et al., 2016; Zhang et al., 2016a; Quanji et al., 2017; Wu et al., 2018). In comparison, the reactive perspective, i.e. the role of contracts when problems occur, has received less attention. Falling into this reactive stream, Chen et al. (2018) put their attention on how prior ties affect parties' severity of contract enforcement after contract breaches. Current literature has yet to identify the drivers of contract application in dealing with disputed claims.

The aforementioned two gaps are closely related to each other and come from two theoretical perspectives - dispute management and contractual governance, respectively. In order to address the gaps, this study aims to identify and analyse factors influencing contractors' behavioural strategies when handling disputed claims. The level of analysis is at the organisational level. This study is expected to make contributions to both theoretical points of departure, which will be thoroughly discussed in the conclusion section.

\section{Research Methodology}




\section{Research Design, Sampling and Data Collection Procedures}

Since current literature reveals possible influencing factors, the authors carried out a literature review to explore a preliminary factor list. Hypotheses were developed accordingly. Then the authors conducted an open-ended questionnaire survey to obtain the degree of impact of these factors and add new factors. Finally, a structured questionnaire survey was carried out to collect quantitative data and test the hypotheses. Chinese contractors were chosen as the target sample because China has played a significant role in the international construction contracting market and will remain active in the market. China owns the largest number (65) of construction contractors in the 2016 Engineering News-Record Top 250 International Contractors list (2016 ENR list for short). The 'Belt and Road' Initiative contributes to the further development of Chinese contractors' overseas business. The criteria for potential respondents in the open-ended (structured) questionnaire survey are practitioners who 1) come from the top 10 (all the 65) Chinese companies in the 2016 ENR list; 2) have settled no less than two (at least one) claim-related dispute(s); and 3) master detailed information regarding both the dispute and the project.

Potential respondents were reached by LinkedIn (since it provides a contact platform and shows practitioners' resumés indicating if they are suitable) or an alumni group of a graduate program on construction management at a famous Chinese university (since some alumni perfectly meet the criteria). Internet-based surveys were used as this mode is beneficial for researchers and respondents, e.g., cost and time saving, easy answer and return (Bryman, 2012).

\section{Data Analysis Method and Power Analysis}

Partial least squares structural equation modelling (PLS-SEM) was adopted to analyse data. As summarised by Hair Jr et al. (2017), PLS-SEM can deal with more than one dependent variable simultaneously and makes no assumptions about data distribution. It estimates parameters by maximising endogenous latent variables' explained variance and is more suitable for research explaining constructs. A power analysis was conducted to calculate the minimum sample size (Cohen, 1992; Hair Jr et al., 2017), which equals 171 (the significance level =0.10, the statistical power $=0.80$, the population effect size $=$ medium, and the number of independent variables $=12$ )

\section{Open-ended Questionnaire Survey and Hypotheses Development}

\section{Factors Identified from the Literature and Hypotheses Development}

Ten possible factors were identified from the literature (see Table 1). Hypotheses were developed as follows.

(1) The disputed amount. When the disputed amount is small compared with the total contract amount, concessions are acceptable since the losses are small. The burden of proof is on 
contractors, who have to spend time and costs in identifying, retrieving and archiving related information, interpreting contracts, and justifying claims (Vidogah and Ndekugri, 1997). Due to expenditures of resources, it is unworthy to enforce their position. Hence, they are likely to choose the relational approach. By contrast, high amounts in controversy merit more strident strategies than low amounts (Hoogenboom and Dale, 2005). Compromises on large amounts may damage the profitability of projects. Thus, contractors are motivated to take the contractual approach to protect interests and avoid massive losses.

Contractors need owners' support in many aspects to complete projects successfully. Fighting over the smallest trifles may bring about owners' antipathy, which negatively affects the relationship. In response to contractors' hostile actions, owners may deliberately provide less support and take stricter monitoring and inspecting procedures. Therefore, small compensations are undeserving of the contractual approach. Instead, contractors prefer the relational approach, which shows cooperation and helps to preserve an amicable relationship (Gilliland and Bello, 2002; Wang et al., 2016). However, the significance of large disputed amounts is self-evident. Heavy reliance on contracts to insist rights is essential for contractors and emotionally acceptable for owners. Thus,

H1: The disputed amount is positively correlated with the contractual approach and negatively correlated with the relational approach.

(2) Procedural fairness. People's behaviours are susceptible to their fairness perception about procedures used to make decisions (Thibaut and Walker, 1975). Contractors may perceive unfairness due to owners' unreasonable disapproval, delayed response, etc. They may attribute negative motivations to owners' actions and lose confidence in cooperation. Hence, contractors attach more importance to individual interests and strive to secure favourable economic outcomes (Aibinu et al., 2008). Moreover, based on equity theory (Adams, 1965), contractors are motivated to retaliate and change the unfair status quo. They prefer to cover the losses caused by unfairness through the contractual approach.

In comparison, procedural justice stimulates a party's relational behaviours as a return for the other party's fair administration (Griffith et al., 2006). In the work setting, employees' procedural fairness perception predicts their extra-role behaviours (Tyler and Blader, 2000). Likewise, contractors who perceive fair procedures may engage in behaviours that are outside of the contract scope and making concessions. Additionally, many studies have consistently found that people are more likely to defer to others' decisions, which are reached via a fair procedure (e.g., Aibinu et al., 2008; Hollander-Blumoff and Tyler, 2008; Murphy and Tyler, 2008). Compliance behaviours are stimulated by procedural fairness, irrespective of whether or not compliance brings losses. Thus, 
H2: Procedural fairness is negatively correlated with the contractual approach and positively correlated with the relational approach.

(3) Time pressure. Contractors perceive time pressure when deadlines are short or time-related expenditures during dispute resolution process are high (Magenau and Pinto, 2004). Owners may put time pressure on contractors by wielding their power to set a limit on how long an agreement should be reached. Without clear deadlines, contractors may also suffer financial losses if the process lasts long. They cannot receive compensations without agreements, which is detrimental to cash flow (Tran and Carmichael, 2013). They have to expedite progress since they are not aware of how many extensions of time will be granted. Claim personnel may spend substantial efforts handling claims, which causes overburdening and prevents them from performing their duties effectively (Gebken II, 2006; Lu and Liu, 2014).

The contractual approach means that contractors insist their own demands to maximise benefits (Lumineau and Malhotra, 2011). It is likely to produce divergences and increase the duration of the resolution process. For instance, dominating behaviours are likely to result in negotiation deadlock (Cheung et al., 2006; Lu, W. et al., 2015b); referring disputes to arbitration has to undergo a long duration before a ruling is provided (Haugen and Singh, 2015). By contrast, concession making contributes to quick agreements (Magenau and Pinto, 2004). Parties under high time pressure tend to cooperate and concede (Stuhlmacher et al., 1998). Conversely, there is no need to give way when contractors face low or no time pressure. They could utilise the contractual approach to press for owners' concessions. Thus,

H3: Time pressure is negatively correlated with the contractual approach and positively correlated with the relational approach.

(4) Favourability of evidence. In order to receive owners' approval or win favourable outcomes if third parties are involved, contractors should demonstrate that their claims are legitimate. However, sometimes it is hard to obtain adequate proof because of poor documentation management (Hassanein and El Nemr, 2008). Additionally, contracts are inevitably incomplete due to bounded rationality (Simon, 1996) or parties' deliberate choices (Chang and Ive, 2007; Duan, 2012). Deficient, ambiguous or inconsistent contract terms may entail controversies regarding the entitlement of claims. Failure to comply with related terms (e.g., the condition precedent) also brings difficulty for justifying claims.

People in conflict often interpret events egoistically (Bazerman and Moore, 2008). Contractors can rely on favourable evidence to impose sanctions on owners, and the probability of obtaining what they deserve is high. Hence, the strong evidence provides an incentive for contractors to 
defend their position and emphasise compensations (Lumineau and Malhotra, 2011; Lumineau and Henderson, 2012). In contrast, weak evidence reduces contractors' bargaining power and ability in achieving desired outcomes (Lu and Liu, 2014). It is hard to affect owners' decisions in a way that benefits contractors. Situations may get worse if third parties are involved since contractors have to face a poor outcome and meanwhile bear the related costs. Therefore, when the evidence is unfavourable, they have nothing to do but cater to owners' viewpoints. Thus,

H4: Favourability of evidence is positively correlated with the contractual approach and negatively correlated with obliging behaviours.

(5) Trust. According to social exchange theory (Blau, 1964), individuals take voluntary actions because they expect returns from others. Such a social exchange involves unspecified future obligations and requires trust. It usually starts with a small exchange, which needs only little trust and involves little risk. Trust will increase if others do reciprocate, and will further develop along with recurrent social exchange over time. Anyone who fails to discharge obligations will be punished by social sanctions, e.g., distrust and no favour.

Trust means that contractors hold positive expectations regarding owners' intentions (Rousseau et al., 1998). They believe that owners will not engage in opportunistic behaviours even in the face of incentives and opportunities (Woolthuis et al., 2005; Gulati and Sytch, 2008). In contractors' viewpoint, owners have reasons, e.g., financial pressure, for decisions. Hence, based on social exchange theory (Blau, 1964), contractors are likely to do owners a favour and expect the favour will be reciprocated in the long run. Although expected reciprocity may not achieve, they are willing to make sacrifices and accept vulnerability. In this regard, contractors tend to adjust themselves to owners' position. Nevertheless, if distrust exists, contractors often hold negative expectations toward owners' motives (Vlaar et al., 2007). Owners' actions are interpreted negatively in the way that they deliberately refuse to approve claims. Contractors are afraid of being vulnerable to exploitation, and thus take strict measures to protect interests (Lu, W. et al., 2015a). Thus,

H5: Trust is negatively correlated with the contractual approach and positively correlated with obliging behaviours.

(6) Shadow of the future. Future consequences caused by current actions will influence a party's current strategy (Chan et al., 2010). It is manifested in four aspects: occurrence time of the dispute, other ongoing project(s), future cooperation and reputation. First, processes of disagreement resolution will influence parties' ability to work together day to day (Mitropoulos and Howell, 2001). Contractors' tough actions during the dispute resolution may bring barriers to 
smooth project implementation. The severity of consequence is intensified when disputes happen in the early phase or when the parties have other ongoing project(s). Second, behavioural strategies constitute a signal about whether contractors are easy-going and flexible. It affects owners' confidence in work with contractors and further influences the possibility of future cooperation. This consequence is severe for contractors who expect future cooperation with the same owner. Third, contractors have high concern for reputation when their behaviours in one project are readily accessible to outsiders. Aggressive actions in problem situations may be spread. If rigidity brings claims to arbitration or litigation, contractors will be shaped into dispute-prone organisations. They have to lower the bidding price or make other sacrifices to win a project due to their damaged reputation ( $\mathrm{Lu}, \mathrm{W}$. et al., 2015a).

Under the shadow of the future, contractors have to pay attention to their behavioural strategies. The contractual approach is competitive and adversarial (Lumineau and Malhotra, 2011). It may negatively affect the relationship and result in detrimental results, e.g., lack of owners' support, stricter monitoring and inspection, no future cooperation, and reputation damage. In order to prohibit those consequences, the shadow of the future directs behaviours towards cooperation and the relational approach. Nevertheless, those consequences are not severe for contractors under a weak shadow of the future. Without fear of future losses, contractors are more likely to attach importance to immediate gains and take the contractual approach. Thus,

H6: Shadow of the future (occurrence time of the dispute, other ongoing project(s), future cooperation and reputation) is negatively correlated with the contractual approach and positively correlated with the relational approach.

(7) Lock-in asymmetry. Lock-in means the degree of losses in terms of time and money caused by replacing partners or withdrawing midway (Chang and Ive, 2007; Zhang et al., 2016b). As explained by Chang and Ive (2007), terminating and leaving a project part-finished may result in enormous losses for owners since specialised assets could be hardly used in other alternatives. If replacing contractors, owners have to bear searching costs and time losses to find a replacement contractor. The impact of project disruption also incurs losses. Contractors may make significant investments in specialised machinery and equipment. The redeployment of material and human assets to alternative uses brings losses if they withdraw midway.

Lock-in effects bring hold-up problems (Chang and Ive, 2007). If an owner's lock-in is higher than a contractor's, the contractor holds more power. The owner could not easily end the relationship in dispute situations due to enormous losses, but the contractor could. This vulnerability is likely to stimulate the contractor's contractual approach. Contrarily, the power 
advantage is owned by the owner. The contractor is worried about the owner's negative response to its competitive approach and thus prefers a relational way. Drawing on interdependence asymmetry (Gundlach and Cadotte, 1994), lock-in asymmetry is the owner's lock-in minus the contractor's lock-in. Thus,

H7: Lock-in asymmetry is positively correlated with the contractual approach and negatively correlated with the relational approach.

\section{Questionnaire Design, Data Collection and Refined Factors}

The first section includes years of working experience in construction project management, professional qualification, and the number of claim-related disputes that the respondent has settled. Then the meanings of factors and behavioural strategies were provided. Respondents were required to assess the degree of impact of these factors on their parties' behavioural strategies according to their experience, on the basis of a 7-point scale (1-very small; 2-small; 3-slightly small; 4-medium; 5-slightly large; 6-large; 7-very large). An open question was designed to add new factors. The following was included in both the open-ended questionnaire and the structured questionnaire to increase the response rate: potential benefits of the survey, importance of respondents' answers, availability of results upon request, time for completing the questionnaire, sponsorship information, confidentiality guarantee, and our email address (Dillman et al., 2014). The authors first developed the questionnaire in English and then translated it into Chinese. A back-translation procedure and a pilot study were conducted to refine the questionnaire. 32 questionnaires were sent out by LinkedIn, and 12 valid questionnaires were received ( 9 from contract administrators, 1 from a project manager, and 2 from cost administrators). The average number of years of working experience is around 13.6, and the average number of disputes that they have resolved is 11 . Hence, they can add general factors by comparing cases.

The authors calculated the mean (M) and standard deviation (SD) of each factor. The degree of impact of favourability of evidence $(\mathrm{M}=6.08 ; \mathrm{SD}=0.79)$, reputation $(\mathrm{M}=5.67 ; \mathrm{SD}=1.56)$ and time pressure $(\mathrm{M}=5.42 ; \mathrm{SD}=0.90)$ ranks first, second and third, respectively. New factors were added. The first one is "the cost of pursuing the disputed claim", i.e. contractors' viewpoint about the cost of pursuing the disputed amount compared with the disputed amount. Claim procedures could be strict and onerous. Contractors may increase contract administrators and even hire consultants from professional companies to justify their rights. Arbitration and litigation also involve high costs (Haugen and Singh, 2015). If contractors think the cost is very high and even outweigh the disputed amount, they would rather satisfy owners' desires. Obliging behaviours also do owners a favour, which improves the relationship and may be returned in the future. By contrast, 
if the expenditure is relatively low, contractors' efforts will not be wasted. They are likely to insist on their position and adopt a contractual approach. The supposed relationship is given in the form of hypothesis: H8: The cost of pursuing the disputed claim is negatively correlated with the contractual approach and positively correlated with obliging behaviours.

The second factor is "cash flow status", i.e. contractors' cash flow status before the dispute happened. Effective cash management is critical to support daily project activities. Contractors in a poor cash position are "hungry" and in desperate need of money. Giving up pursuing rights undoubtedly worsens the grave financial situation, and thus obliging is suppressed. The contractual approach may alleviate the financial problem but at a risk of an impasse. Contractors may not obtain compensations timely, which is unacceptable for those with bad cash flow. Besides, they are not financially capable of withstanding the related costs. Hence, the degree of using the contractual approach seems to be higher for contractors with good cash flow than those with poor cash flow. Compromising behaviours not only help to recover losses but also achieve a settlement quickly. The degree of adopting compromising behaviours seems to be higher for contractors with poor cash flow than those with good cash flow. Thus, H9: Contractors' poor cash flow is negatively correlated with the contractual approach and obliging behaviours, and positively correlated with compromising behaviours.

One respondent added a third factor - the host country of a project, which was excluded because it is not at the organisational level. It should be noted that this study relies on nomothetic explanation, with the aim of identifying several causes that generally work in many projects rather than complete causes that work in a single project (Babbie, 2011).

\section{Structured Questionnaire Survey and Data Analyses}

\section{Measures of Variables, Questionnaire Design and Data Collection}

All the measures were developed based on previous studies (see Table 2). On the premise of not violating the original meanings, minor modifications were made to suit the research context. Respondents were asked to recall a claim-related dispute that they recently settled on behalf of the contractor and this dispute's related project information to answer this questionnaire. The first section covers years of working experience in construction project management, professional qualification, enterprise types of the contractor and the owner, whether the two parties are from the same country, project type, contract type, and project location. The drivers and behavioural strategies were measured in the following two sections. The disputed amount and the cost of pursuing the disputed claim were measured by a 7-point scale (1-very low; 2-low; 3-slightly low; 4-medium; 5-slightly high; 6-high; 7-very high). Occurrence time of the dispute was chosen from 
five options (less than $20 \%, 20-40 \%, 41-60 \%, 61-80 \%$, or more than $80 \%$ ), and other ongoing project(s) from two options (yes or no). Other drivers and behavioural strategies were assessed on a 7-point Likert scale (1-strongly disagree; 2-disagree; 3-slightly disagree; 4-neutral; 5-slight agree; 6-agree; 7-strongly agree). A back-translation procedure and a pilot study were also conducted. Due to the length limitation, the survey scales are available upon request.

The authors sent out 834 questionnaires by LinkedIn and 11 by the alumni group and received 248 valid questionnaires. The effective response rate is $29.3 \%$. Table 3 provides the sample characteristics. $73.4 \%$ of the valid questionnaires are based on projects outside China. The global distribution of project locations enhances the external validity of this study.

\section{Common Method Variance and Descriptive Statistics}

The authors took remedies to mitigate common method variance (CMV) (Podsakoff et al., 2003). Answers were anonymous, and respondents were told that there are no right or wrong answers. The items were improved by pilot studies, and the labels for the midpoints of scales were provided. The result of Harman's single-factor test showed that more than one factor was extracted, and the first factor only explained $15.711 \%$ of the total variance. Therefore, CMV is not of concern. The descriptive statistics are given in Table S1 in the supplemental data. The largest correlation coefficient is 0.486 , which means that correlations among the independent variables are fairly modest and not excessive. In order to further assess potential collinearity problems, variance inflation factors (VIFs) were examined. The largest VIF value is 1.474 , which is much smaller than the threshold of 5 (Hair Jr et al., 2011). Hence, there is no collinearity problem.

\section{Algorithm Settings and Evaluation of Measurement Models}

SmartPLS was applied to analyse the data. Four settings were "Path Weighting", +1 as the initial values for outer weights and loadings, $10^{-7}$ as the stop criterion, and 300 as the maximum number of iterations (Hair Jr et al., 2017). The number of iterations was 15, so the results stabilised. The authors evaluated the reliability and validity of reflective multiple-indicator measures (see results in Tables S2-S7 in the supplemental data). First, all values of Cronbach's alpha and composite reliability exceed 0.60 (Hair Jr et al., 2017), and thus the internal consistency reliability is good. Second, all outer loadings and AVE values are above 0.4 and 0.5, respectively (Hair Jr et al., 2017). The convergent validity is satisfactory. Third, all indicators' outer loadings on their associated constructs are greater than their cross-loadings. The square root of any reflective construct's AVE value is greater than its highest correlation with other constructs. The HTMT values are lower than the threshold value of 0.9, and all confidence intervals do not include 1 (Hair Jr et al., 2017). The discriminant validity is good. 


\section{Evaluation of the Structural Model}

Four settings for the bootstrapping procedure were 5000 bootstrap samples, "No Sign Changes", "Bias-Corrected and Accelerated (BCa) Bootstrap", and "Two-Tailed". Figure 1 shows the significant relationships (also see Table S8 in the supplemental data). The disputed amount is positively correlated with the contractual approach and negatively correlated with the relational approach, supporting H1. Procedural fairness is negatively correlated with obliging behaviours, rejecting H2. Time pressure is positively correlated with the relational approach, partially supporting H3. Favourability of evidence is positively correlated with the contractual approach and negatively correlated with obliging behaviours, supporting H4. Consistent with H5, trust is negatively correlated with the contractual approach and positively correlated with obliging behaviours. Occurrence time of the dispute and future cooperation are positively correlated with obliging behaviours. Other ongoing project(s), future cooperation and reputation are positively correlated with compromising behaviours. H6 is partially supported. The impact of lock-in asymmetry is not significant, repudiating H7. The cost of pursuing the disputed claim is negatively correlated with the contractual approach and positively correlated with obliging behaviours, supporting H8. Contractors' poor cash flow is negatively correlated with obliging behaviours, partially supporting $\mathrm{H} 9$. The $\mathrm{R}^{2}$ values of the contractual approach, obliging and compromising behaviours are $0.159,0.229$ and 0.235 , respectively.

\section{Discussions}

\section{Unexpected Findings - How do Procedural Fairness and Occurrence Time of the Dispute Play a} Role?

Procedural fairness is negatively correlated with obliging behaviours. It seems to contradict the wisdom that procedural fairness leads to compliance behaviours, which is based on Tyler's (1990) procedural justice model and has been supported in different contexts (e.g., Aibinu et al., 2008; Reisig et al., 2014). However, in this study, disputes appear when contractors reject owners' decisions on claims. It is a precondition that does not exist in those studies. In fact, Tyler's (1990) theory holds a less calculative perspective on people's reactions. If authorities wield authority fairly, people will perceive authorities' legitimacy and further choose compliance. An alternative perspective is calculative, i.e. people's behaviours are influenced by anticipation of reward or fear of punishment (Tyler, 2006). Contractors who engage in disputes usually attach great importance to instrumental concerns. Fair procedures reflect that owners stick to contract principles, which increases the likelihood of obtaining compensations due. The dominant instrumental motivation may account for this finding. This explanation is consistent with the argument that procedural 
fairness may affect behaviours through the non-instrumental channel and instrumental channel (Dickson et al., 2014). It should be stressed that this finding does not mean that owners had better adopt unfair procedures. Contractors who receive unfavourable decisions on claims are more likely to engage in disputes if they perceive unfair procedures (Aibinu et al., 2008). Therefore, fair procedures are conducive to preventing disputes. If disputes occur, unfair treatment may help owners to grasp unbalanced benefits temporarily. However, contractors choose obliging since owners' oppression makes them hopeless. Such opportunistic behaviours will weaken contractors' willingness of cooperation and commitment (Luo, 2006; Wang and Yang, 2013). Moreover, information advantages usually lie with contractors (Fu et al., 2015). They may take advantage of information asymmetry to recover losses (shirk responsibilities, cut corners, etc.). Eventually, project performance will be negatively affected. Thus, owners are sensible to handle claims in a fair way and do not make situations worse for all involved.

Another unexpected result is that the later a dispute occurs, the more likely contractors are to take obliging behaviours. It implies that there are other mechanisms, exerting stronger and opposite effects. One explanation is that contractors are unwilling to be seen as soft in the early stage. If they do not actively defend their rights from the very beginning, owners may take advantage of such weakness. It will be very tough for contractors to pursue rights later. This explanation is similar to the anchoring effect of initial offers in negotiations, i.e. the toughness of a party's initial offer predicts a better outcome (Van Poucke and Buelens, 2002). Contractors' obliging behaviours in the early stage may be a reference point for owners to make the following judgments and decisions. Another possibility is that owners also have the shadow of the future. They usually suffer from a heavy pressure of construction progress in the early phase and thus hold a positive attitude towards problem-solving. They are afraid that if claims are not solved successfully, contractors may work passively. Contractors who realise this are unlikely to take obliging behaviours. In contrast, owners' concern is little in the late phase, especially after taking over projects. The decreasing reliance brings difficulty for contractors to pursue disputed entitlements, which increases obliging behaviours. This explanation echoes Chan's (2010) observation that the host government will be less dependent on the investor when the project passes from construction to operation, and the investor will be in a weak position.

\section{Which Drivers Exert the Largest Impact on Behavioural Strategies?}

The values of path coefficients show the degree of impact. Favourability of evidence has the largest influence on the contractual approach and is negatively correlated with obliging behaviours. The finding is in line with $\mathrm{Lu}$ and Liu (2014), who found that sufficiency of evidence contributes to 
contractors' bargaining power in construction dispute negotiations. Thus, contractors are advised to improve the favourability of evidence. Ambiguous or inconsistent contract provisions should be avoided when negotiating the contract. During contract execution, an experienced contractor not only has good knowledge of evidence sources but also keeps contemporary records in a focused manner. Supporting particulars should be well preserved and not subject to unexpected events (e.g., the turnover of key people on site, an unexpected deadline for submission required by owners). Moreover, procedural requirements under contracts should be met to avoid losing entitlements.

As for obliging behaviours, time pressure is the most important driver. The result is consistent with previous studies (Stuhlmacher et al., 1998; Lu and Liu 2014). Contractors should be aware of potential consequences caused by long resolution process. It is advisable to avoid suffering from time pressure. If compromising brings quick resolution and the losses are acceptable, contractors are supposed to do so. The longer the dispute resolution process lasts, the weaker their bargaining position will be. Regarding compromising behaviours, reputation plays the most important role, and future cooperation ranks second. Other ongoing project(s) also has an effect. These three bring the shadow of the future. Previous studies have supported a similar impact (Marzouk and Moamen, 2009; Chan et al., 2010; Zhang et al., 2016b). The noteworthy point is that future cooperation is positively correlated with not only compromising but also obliging behaviours, which echoes the case in the introduction. The effect of other ongoing project(s) implies that an owner is suggested to cooperate with the contractor, who is undertaking a project of the owner, on other projects, if the contractor is suitable and the current interaction is positive.

Trust has the second largest impact on the contractual approach and the third largest impact on obliging behaviours. Similarly, Faems et al. (2008) showed that trust stimulates flexible contract application while distrust fosters rigidity in exploratory R\&D alliances. Zhang et al. (2016b) found that trust is positively correlated with the interest-based behavioural strategy in construction subcontracting dispute negotiations. Thus, owners are encouraged to develop trust from the very beginning. However, they should not utilise trust. When a party takes advantage of the other party, its behaviours are perceived as slightly negative if the other party distrusts it but very negative if the other party trusts it (Weber, 2017). Indeed, owners' opportunistic behaviours will break contractors' positive expectation and be viewed as betrayal and exploitation. Trust will break down since then. Aggrieved contractors are likely to retaliate with tough responses in the future. If owners are in a difficult position, a sensible solution is to explain problems honestly and compensate contractors in other ways. A party's trust will increase if the other party pays back for favours in the future, otherwise will be violated (Blau, 1964). 


\section{Conclusion}

This study identifies eleven factors that significantly affect contractors' behavioural strategies when dealing with disputed claims. A high disputed amount, high favourability of evidence, low trust and low cost of pursuing the disputed claim are causes of contractors' contractual approach. High time pressure, high trust, late occurrence time of the dispute, high expectation about future cooperation, high cost of pursuing the disputed claim, low disputed amount, procedural unfairness, low favourability of evidence and contractors' good cash flow account for contractors' obliging behaviours. High time pressure, the existence of other ongoing project(s), high expectation about future cooperation, high concern about reputation and low disputed amount are reasons for contractors' compromising behaviours.

\section{Theoretical and Practical Contributions}

This study makes contributions to the body of knowledge on both dispute management and contractual governance. First, rigid contract application in dispute situations is not limited to negotiations. Therefore, the scope of this study is the whole dispute resolution process. Although Chan et al. (2010) investigated the effects of three kinds of drivers on investors' behavioural strategies of dispute resolution, their focus is on investors' approaches to solve government-initiated renegotiation problems. In contrast, this study presents a nuanced picture of how multiple factors influence contractors' behavioural strategies of claim-related dispute resolution. The results constitute a supplement to the construction dispute management literature regarding drivers of behavioural strategies. Second, from the theoretical perspective of contractual governance, how to employ contracts to solve problems in construction projects is still in its infancy. This is a general topic and needs to be narrowed down to provide deeper insights. This study focuses on one specific problem, i.e. claim-related dispute resolution, and analyses contractors' rigid and flexible contract application in this problem situation. Hence, it enriches the contractual governance research from the reactive perspective and hopefully will stimulate more related research in the field of construction management. Third, drivers of contract application in problem situations have been investigated in other industries, such as supply chain management and strategy management (e.g., Faems et al., 2008; Johnson and Sohi, 2016). Specific to the construction industry, Chen et al. (2018) revealed the impact of prior ties on a party's general level of severity of contract enforcement in a project after the other party's contract violations. Unlike their research, this study is limited to contractors' responses to one particular problem. The findings furnish a fine-grained understanding of multiple factors' different impacts on contractors' contract application in dealing with disputed claims and thus extend the body of knowledge on drivers of contract application in problem situations. 
In addition to theoretical contributions, this study contributes to the industry in three main ways. First, this study is conducive to contractors' awareness of potential influencing factors behind their behavioural decisions. When selecting their behavioural strategies, inexperienced contractors may be unaware of the elements that need to be considered and hesitate to make a choice. The findings help to avoid contractors' blind decision-making in resolving disputed claims. Second, this study deepens owners' cognition of contractors' behavioural choices. Owners may predict contractors' possible behavioural strategies according to actual situations, and then reorient their own responses to resolve disputes efficiently. If contractors are expected to take the contractual approach, approving legitimate claims is a suggested solution for owners. Third, this study provides insights into both parties' ex-ante focus of attention on drivers. They may make efforts to change the values of some drivers in advance to facilitate the subsequent dispute resolution process, as explained in the previous section.

\section{Limitations and Future Research}

First, one common limitation of cross-sectional design is the ambiguity about the direction of causal influence (Bryman, 2012). In the structured questionnaire survey, most factors measured happened before the adoption of behavioural strategies. The open-ended questionnaire survey largely reduces the possibility of reverse time sequence and spurious correlation. Thus, the internal validity is improved (Babbie, 2011). Second, this study belongs to single-level research, which reduces the complexity of phenomena but only provides partial explanations. Future research may take a multilevel perspective to enrich theories. Third, the unexpected findings about procedural fairness and occurrence time of the dispute suggest that it might be worthy for future studies to explore their mediating mechanisms. Fourth, researchers are recommended to examine rigid and flexible contract application to solve problems in other contexts, e.g., how owners enforce contracts when contractors fail to behave as contracted.

\section{References}

Adams, J.S. (1965), "Inequity in social exchange", Advances in Experimental Social Psychology, Vol. 2, pp. 267-299.

Aibinu, A.A., Ling, F.Y.Y. and Ofori, G. (2011), "Structural equation modelling of organisational justice and cooperative behaviour in the construction project claims process: contractors' perspectives", Construction Management \& Economics, Vol. 29 No. 5, pp. 463-481.

Aibinu, A.A., Ofori, G. and Ling, F.Y. (2008), "Explaining cooperative behaviour in building and civil engineering projects' claims process: Interactive effects of outcome favourability and procedural fairness", Journal of Construction Engineering and Management, Vol. 134 No. 9, pp. 681-691. 
Antia, K.D. and Frazier, G.L. (2001), "The severity of contract enforcement in interfirm channel relationships", Journal of Marketing, Vol. 65 No. 4, pp. 67-81.

Awwad, R., Barakat, B. and Menassa, C. (2016), "Understanding dispute resolution in the Middle East region from perspectives of different stakeholders", Journal of Management in Engineering, Vol. 32 No. 6, 05016019.

Babbie, E.R. (2011), The Practice of Social Research, 13th ed., Wadsworth, Belmont, CA.

Bazerman, M., and Moore, D. (2008), Judgment in Managerial Decision Making, 7th ed., John Wiley \& Sons, New York, NY.

Blau, P.M. (1964), Exchange and Power in Social Life, John Wiley \& Sons, New York, NY.

Bryman, A. (2012), Social Research Methods, 4th ed., Oxford University Press, Oxford, UK.

Carson, S.J., Madhok, A. and Wu, T. (2006), "Uncertainty, opportunism, and governance: The effects of volatility and ambiguity on formal and relational contracting", Academy of Management Journal, Vol. 49 No. 5, pp. 1058-1077.

Chan, E.H.W., Suen, H.C. and Chan, C.K. (2006), "MAUT-based dispute resolution selection model prototype for international construction projects”, Journal of Construction Engineering and Management, Vol. 132 No. 5, pp. $444-451$.

Chan, H., Levitt, R. and Garvin, M. (2010). "Collectives effect of strategic, cultural, and institutional factors on concession renegotiations", Paper presented at the 2010 Engineering Project Organization Conference, South Lake Tahoe, CA, 4-7 November.

Chang, C.Y. and Ive, G. (2007), "Reversal of bargaining power in construction projects: meaning, existence and implications", Construction Management \& Economics, Vol. 25 No. 8, pp. 845-855.

Chen, Y.T., Chen, Y.Q., Liu, Z.J. and Yao, H.J. (2018), "Influence of prior ties on trust in contract enforcement in the construction industry: Moderating role of the shadow of the future", Journal of Management in Engineering, Vol. 34 No. 2, 04017064.

Cheung, S.O. and Chow, P.T. (2011), "Withdrawal in construction project dispute negotiation", Journal of Construction Engineering and Management, Vol. 137 No. 12, pp. 1071-1079.

Cheung, S.O. and Pang, K.H.Y. (2013), “Anatomy of construction disputes”, Journal of Construction Engineering and Management, Vol. 139 No. 1, pp. 15-23.

Cheung, S.O., Yiu, T.W. and Yeung, S.F. (2006), "A study of styles and outcomes in construction dispute negotiation", Journal of Construction Engineering and Management, Vol. 132 No. 8, pp. 805-814.

Chong, H.Y. and Zin, R.M. (2012), "Selection of dispute resolution methods: Factor analysis approach", Engineering, Construction and Architectural Management, Vol. 19 No. 4, pp. 428-443.

Cohen, J. (1992), “A power primer”, Psychological Bulletin, Vol. 112 No. 1, pp. 155-159.

Dickson, E., Gordon, S.C. and Huber, G.A. (2014), "Procedural justice and legitimate authority”, available at: 
https://www.nyu.edu/projects/gordon/Procedure_and_Legitimacy_3.2_clean.pdf (accessed 16 November 2017). Dillman, D.A., Smyth, J.D. and Christian, L.M. (2014), Internet, Phone, Mail, and Mixed-Mode Surveys: The Tailored Design Method, 4th ed., John Wiley \& Sons, Hoboken, NJ.

Duan, M. (2012), “The role of formal contracts with weak legal enforcement: A study in the Chinese context", Strategic Organization, Vol. 10 No. 2, pp. 158-186.

Faems, D., Janssens, M., Madhok, A. and Van Looy, B. (2008), "Toward an integrative perspective on alliance governance: Connecting contract design, trust dynamics, and contract application”, Academy of Management Journal, Vol. 51 No. 6, pp. 1053-1078.

Fu, Y., Chen, Y., Zhang, S. and Wang, W. (2015), "Promoting cooperation in construction projects: an integrated approach of contractual incentive and trust", Construction Management \& Economics, Vol. 33 No. 8, pp. 653-670.

Gad, G.M., Kalidindi, S.N., Shane, J. and Strong, K. (2011), “Analytical framework for the choice of dispute resolution methods in international construction projects based on risk factors", Journal of Legal Affairs and Dispute Resolution in Engineering and Construction, Vol. 3 No. 2, pp. 79-85.

Gebken II, R.J. (2006), Quantification of Transactional Dispute Resolution Costs for the United States Construction Industry (Doctoral dissertation), The University of Texas at Austin.

Gilliland, D.I. and Bello, D.C. (2002), "Two sides to attitudinal commitment: The effect of calculative and loyalty commitment on enforcement mechanisms in distribution channels", Journal of the Academy of Marketing Science, Vol. 30 No. 1, pp. 24-43.

Griffith, D.A., Harvey, M.G. and Lusch, R.F. (2006), "Social exchange in supply chain relationships: The resulting benefits of procedural and distributive justice", Journal of Operations Management, Vol. 24 No. 2, pp. 85-98.

Gulati, R. and Sytch, M. (2008), "Does familiarity breed trust? Revisiting the antecedents of trust", Managerial and Decision Economics, Vol. 29 No. 2-3, pp. 165-190.

Gundlach, G.T. and Cadotte, E.R. (1994), "Exchange interdependence and interfirm interaction: Research in a simulated channel setting”, Journal of Marketing Research, Vol. 31 No. 4, pp. 516-532.

Hair Jr, J.F., Hult, G.T.M., Ringle, C.M. and Sarstedt, M. (2017), A Primer on Partial Least Squares Structural Equation Modeling (PLS-SEM), 2nd ed., Sage Publications, Thousand Oaks, CA.

Hair Jr, J.F., Ringle, C.M. and Sarstedt, M. (2011), "PLS-SEM: Indeed a silver bullet", Journal of Marketing Theory and Practice, Vol. 19 No. 2, pp. 139-152.

Hassanein, A.A. and El Nemr, W. (2008), "Claims management in the Egyptian industrial construction sector: A contractor's perspective", Engineering, Construction and Architectural Management, Vol. 15 No. 5, pp. 456-469.

Haugen, T. and Singh, A. (2015), "Dispute resolution strategy selection", Journal of Legal Affairs and Dispute 
Resolution in Engineering and Construction, Vol. 7 No. 3, 05014004.

Hollander-Blumoff, R. and Tyler, T.R. (2008), "Procedural justice in negotiation: Procedural fairness, outcome acceptance, and integrative potential”, Law \& Social Inquiry, Vol. 33 No. 2, pp. 473-500.

Hoogenboom, J. and Dale, W.S. (2005), “Dispute resolution strategy and decision analysis,” Paper presented at the 49th Annual Meeting of the Association for the Advancement of Cost Engineering International, New Orleans, LA.

Jiang, X., Li, M., Gao, S., Bao, Y. and Jiang, F. (2013), "Managing knowledge leakage in strategic alliances: The effects of trust and formal contracts", Industrial Marketing Management, Vol. 42 No. 6, pp. 983-991.

Johnson, J.S. and Sohi, R.S. (2016), "Understanding and resolving major contractual breaches in buyer-seller relationships: A grounded theory approach", Journal of the Academy of Marketing Science, Vol. 44 No. 2, pp. 185-205.

Kong, D.T., Dirks, K.T. and Ferrin, D.L. (2014), “Interpersonal trust within negotiations: Meta-analytic evidence, critical contingencies, and directions for future research", Academy of Management Journal, Vol. 57 No. 5, pp. 1235-1255.

Kumaraswamy, M.M. (1997), “Conflicts, claims and disputes in construction”, Engineering, Construction and Architectural Management, Vol. 4 No. 2, pp. 95-111.

Lee, C.K., Yiu, T.W. and Cheung, S.O. (2018), “Understanding intention to use alternative dispute resolution in construction projects: Framework based on technology acceptance model", Journal of Legal Affairs and Dispute Resolution in Engineering and Construction, Vol. 10 No. 1, 04517021.

Lin, X. and Germain, R. (1998), "Sustaining satisfactory joint venture relationships: The role of conflict resolution strategy", Journal of International Business Studies, Vol. 29 No. 1, pp. 179-196.

Liu, Y., Huang, Y., Luo, Y. and Zhao, Y. (2012), "How does justice matter in achieving buyer-supplier relationship performance?", Journal of Operations Management, Vol. 30 No. 5, pp. 355-367.

Lu, P., Guo, S., Qian, L., He, P. and Xu, X. (2015). “The effectiveness of contractual and relational governances in construction projects in China”, International Journal of Project Management, Vol. 33 No. 1, pp. 212-222.

Lu, W., Li, Z. and Wang, S. (2017), "The role of justice for cooperation and contract's moderating effect in construction dispute negotiation", Engineering, Construction and Architectural Management, Vol. 24 No. 1, pp. $133-153$.

Lu, W. and Liu, J. (2014), "Research into the moderating effects of progress and quality performance in project dispute negotiation”, International Journal of Project Management, Vol. 32 No. 4, pp. 654-662.

Lu, W., Zhang, L. and Li, Z. (2015b), "Influence of negotiation risk attitude and power on behaviours and outcomes when negotiating construction claims", Journal of Construction Engineering and Management, Vol. 141 No. 2, 04014069. 
Lu, W., Zhang, L. and Pan, J. (2015a), "Identification and analyses of hidden transaction costs in project dispute resolutions", International Journal of Project Management, Vol. 33 No. 3, pp. 711-718.

Lu, W., Zhang, L. and Zhang, L. (2016), "Effect of contract completeness on contractors' opportunistic behaviour and the moderating role of interdependence", Journal of Construction Engineering and Management, Vol. 142 No. 6,04016004 .

Lui, S.S. and Ngo, H.Y. (2012), "Drivers and Outcomes of Long-term Orientation in Cooperative Relationships", British Journal of Management, Vol. 23 No. 1, pp. 80-95.

Lumineau, F. and Henderson, J.E. (2012), "The influence of relational experience and contractual governance on the negotiation strategy in buyer-supplier disputes", Journal of Operations Management, Vol. 30 No. 5, pp. $382-395$.

Lumineau, F. and Malhotra, D. (2011), "Shadow of the contract: How contract structure shapes interfirm dispute resolution", Strategic Management Journal, Vol. 32 No. 5, pp. 532-555.

Lumineau, F. and Oxley, J. E. (2012), "Let's work it out (or we'll see you in court): litigation and private dispute resolution in vertical exchange relationships", Organization Science, Vol. 23 No. 3, pp. 820-834.

Luo, Y. (2006), "Opportunism in inter-firm exchanges in emerging markets", Management and Organization Review, Vol. 2 No. 1, pp. 121-147.

Magenau, J.M. and Pinto, J.K. (2004), "Power, influence and negotiation in project management", In P.W.G. Morris and J.K. Pinto (Eds.), The Wiley Guide to Managing Projects (pp. 1033-1060), John Wiley \& Sons, Hoboken, NJ.

Marzouk, M., El-Mesteckawi, L. and El-Said, M. (2011), "Dispute resolution aided tool for construction projects in Egypt", Journal of Civil Engineering and Management, Vol. 17 No. 1, pp. 63-71.

Marzouk, M. and Moamen, M. (2009), “A framework for estimating negotiation amounts in construction projects", Construction Innovation, Vol. 9 No. 2, pp. 133-148.

Mathieu, J. E. and Chen, G. (2011), “The etiology of the multilevel paradigm in management research”, Journal of Management, Vol. 37 No. 2, pp. 610-641.

Mitropoulos, P. and Howell, G. (2001), "Model for understanding, preventing, and resolving project disputes", Journal of Construction Engineering and Management, Vol. 127 No. 3, pp. 223-231.

Murphy, K. and Tyler, T. (2008). "Procedural justice and compliance behaviour: The mediating role of emotions", European Journal of Social Psychology, Vol. 38 No. 4, pp. 652-668.

Park, H.K., Han, S.H. and Russell, J.S. (2005), "Cash flow forecasting model for general contractors using moving weights of cost categories", Journal of Management in Engineering, Vol. 21 No. 4, pp. 164-172.

Podsakoff, P.M., MacKenzie, S.B., Lee, J.Y. and Podsakoff, N.P. (2003), "Common method biases in behavioural research: a critical review of the literature and recommended remedies", Journal of Applied Psychology, Vol. 88 
No. 5, pp. 879-903.

Poppo, L., Zhou, K.Z. and Ryu, S. (2008), “Alternative origins to interorganisational trust: An interdependence perspective on the shadow of the past and the shadow of the future", Organization Science, Vol. 19 No. 1, pp. $39-55$.

Quanji, Z., Zhang, S. and Wang, Y. (2017), "Contractual governance effects on cooperation in construction projects: Multifunctional approach", Journal of Professional Issues in Engineering Education and Practice, Vol. 143 No. 3, 04016025.

Rahim, M.A. (2002), “Toward a theory of managing organisational conflict”, International Journal of Conflict Management, Vol. 13 No. 3, pp. 206-235.

Reisig, M.D., Tankebe, J. and Mesko, G. (2014), "Compliance with the law in Slovenia: The role of procedural justice and police legitimacy", European Journal on Criminal Policy and Research, Vol. 20 No. 2, pp. 259-276.

Rousseau, D.M., Sitkin, S.B., Burt, R.S. and Camerer, C. (1998), "Not so different after all: A cross-discipline view of trust", Academy of Management Review, Vol. 23 No. 3, pp. 393-404.

Simon, H.A. (1996), The Sciences of the Artificial, 3rd ed., MIT Press, Cambridge, MA.

Stuhlmacher, A.F., Gillespie, T.L. and Champagne, M.V. (1998), "The impact of time pressure in negotiation: A meta-analysis", International Journal of Conflict Management, Vol. 9 No. 2, pp. 97-116.

Thibaut, J. and Walker, L. (1975), Procedural Justice: A Psychological Analysis, Erlbaum, Hillsdale, NJ.

Tran, H. and Carmichael, D.G. (2013), “A contractor's classification of owner payment practices”, Engineering, Construction and Architectural Management, Vol. 20 No. 1, pp. 29-45.

Tyler, T.R. (1990), Why People Obey the Law, Yale University Press, New Haven, CT.

Tyler, T.R. (2006), "Psychological perspectives on legitimacy and legitimation", Annual Review of Psychology, Vol. 57, pp. 375-400.

Tyler, T.R. and Blader, S.L. (2000), Cooperation in Groups: Procedural Justice, Social Identity, and Behavioural Engagement, Psychology Press, Philadelphia, PA.

Van Kleef, G.A., De Dreu, C.K. and Manstead, A.S. (2004), "The interpersonal effects of emotions in negotiations: a motivated information processing approach", Journal of Personality and Social Psychology, Vol. 87 No. 4, pp. 510-528.

Van Poucke, D. and Buelens, M. (2002), "Predicting the outcome of a two-party price negotiation: Contribution of reservation price, aspiration price and opening offer", Journal of Economic Psychology, Vol. 23 No. 1, pp. $67-76$.

Vidogah, W. and Ndekugri, I. (1997), “Improving management of claims: contractors' perspective”, Journal of Management in Engineering, Vol. 13 No. 5, pp. 37-44.

Vlaar, P.W., Van den Bosch, F.A. and Volberda, H.W. (2007), "On the evolution of trust, distrust, and formal 
coordination and control in interorganisational relationships toward an integrative framework", Group \& Organization Management, Vol. 32 No. 4, pp. 407-428.

Wang, C.L., Lin, X., Chan, A.K. and Shi, Y. (2005), "Conflict handling styles in international joint ventures: A cross-cultural and cross-national comparison", MIR: Management International Review, Vol. 45 No. 1, pp. 3-21.

Wang, X. and Yang, Z. (2013), "Inter-firm opportunism: a meta-analytic review and assessment of its antecedents and effect on performance”, Journal of Business \& Industrial Marketing, Vol. 28 No. 2, pp. 137-146.

Wang, Y., Wang, K.Y. and Ma, X. (2016), “Understanding international business negotiation behaviour: Credible commitments, dispute resolution, and the role of institutions", International Negotiation, Vol. 21 No. 1, pp. 165-198.

Weber, L. (2017), “A sociocognitive view of repeated interfirm exchanges: How the coevolution of trust and learning impacts subsequent contracts”, Organization Science, Vol. 28 No. 4, pp. 744-759.

Woolthuis, R.K., Hillebrand, B. and Nooteboom, B. (2005), "Trust, contract and relationship development", Organization Studies, Vol. 26 No. 6, pp. 813-840.

Wu, G., Zhao, X., Zuo, J. and Zillante, G. (2018), "Effects of contractual flexibility on conflict and project success in megaprojects”, International Journal of Conflict Management, Vol. 29 No. 2, pp. 253-278.

Yiu, T.W., Keung, C.W. and Wong, K.L. (2011), "Application of equity sensitivity theory to problem-solving approaches in construction dispute negotiation", Journal of Management in Engineering, Vol. 27 No. 1, pp. 40-47.

Zhang, S.B., Fu, Y.F., Gao, Y. and Zheng, X.D. (2016b), "Influence of trust and contract on dispute negotiation behavioural strategy in construction subcontracting", Journal of Management in Engineering, Vol. 32 No. 4, 04016001.

Zhang, S.B., Zhang, S.J, Gao, Y. and Ding, X.M. (2016a), “Contractual governance: Effects of risk allocation on contractors' cooperative behaviour in construction projects", Journal of Construction Engineering and Management, Vol. 142 No. 6, 04016005. 


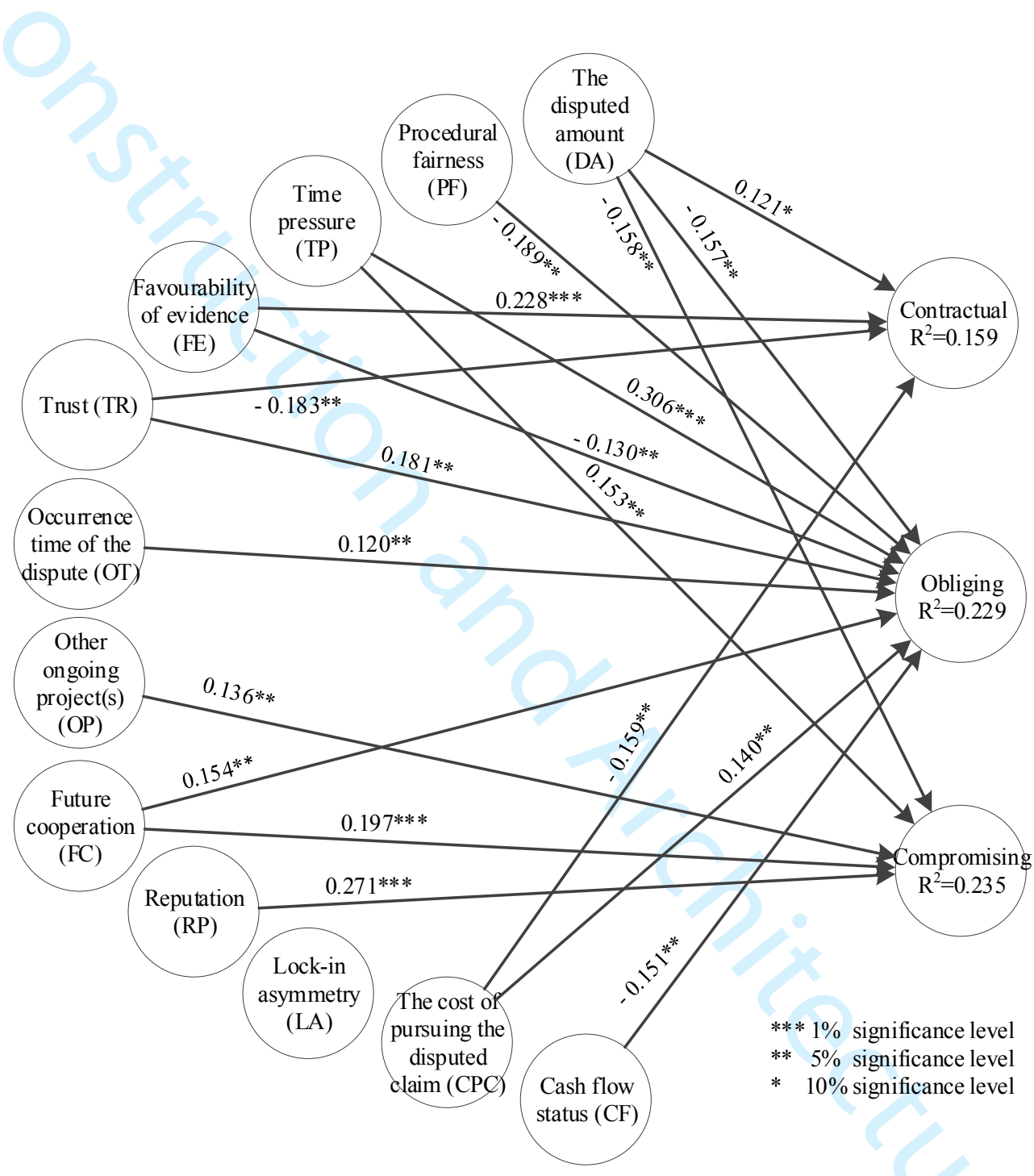

Figure 1. Graphical results 
Table 1. Descriptions of factors identified from the literature

\begin{tabular}{|c|c|c|}
\hline Factors & Descriptions & Sources \\
\hline 1. The disputed amount & The ratio of the disputed claim amount to the total contract amount & $\begin{array}{l}\text { Marzouk and Moamen (2009); Marzouk et } \\
\text { al. (2011); Zhang et al. (2016b) }\end{array}$ \\
\hline 2. Procedural fairness & Fairness perception about procedures used by the owner for dealing with the claim & $\begin{array}{l}\text { Aibinu et al. (2008); Aibinu et al. (2011); } \\
\text { Lu et al. (2017) }\end{array}$ \\
\hline 3. Time pressure & $\begin{array}{l}\text { The desire to find solutions quickly because of negative consequences caused by } \\
\text { the long duration of dispute resolution process }\end{array}$ & $\begin{array}{l}\text { Stuhlmacher et al. (1998); Marzouk et al. } \\
\text { (2011); Lu and Liu (2014) }\end{array}$ \\
\hline 4. Favourability of evidence & The degree of favourability of collected evidence supporting the claim & Marzouk et al. (2011); Lu and Liu (2014) \\
\hline 5. Trust & $\begin{array}{l}\text { The contractor's positive expectation of the owner's good intention to perform in a } \\
\text { trustworthy way before the dispute happened }\end{array}$ & $\begin{array}{l}\text { Faems et al. (2008); Kong et al. (2014); } \\
\text { Zhang et al. (2016b) }\end{array}$ \\
\hline $\begin{array}{l}\text { 6. Shadow of the future - occurrence time of the } \\
\text { dispute }\end{array}$ & $\begin{array}{l}\text { The percentage of the total contract duration that had been completed until the } \\
\text { dispute happened }\end{array}$ & Lumineau and Oxley (2012) \\
\hline 7. Shadow of the future - other ongoing project(s) & The existence of other ongoing project(s) with the same owner & $\begin{array}{l}\text { Marzouk and Moamen (2009); Chan et al. } \\
\text { (2010) }\end{array}$ \\
\hline 8. Shadow of the future - future cooperation & $\begin{array}{l}\text { Expectation about future cooperation with the same owner before the dispute } \\
\text { happened }\end{array}$ & $\begin{array}{l}\text { Marzouk and Moamen (2009); Chan et al. } \\
\text { (2010); Zhang et al. (2016b) }\end{array}$ \\
\hline 9. Shadow of the future - reputation & Concern about reputation before the dispute happened & Marzouk and Moamen (2009) \\
\hline 10. Lock-in & $\begin{array}{l}\text { The degree of losses in terms of time and money caused by replacing partners or } \\
\text { withdrawing midway before the dispute happened, including the owner's lock-in } \\
\text { and the contractor's lock-in }\end{array}$ & $\begin{array}{l}\text { Antia and Frazier (2001); Chang and Ive } \\
\text { (2007) }\end{array}$ \\
\hline
\end{tabular}


Table 2. Measures of variables

\begin{tabular}{|c|c|c|}
\hline Variables & Reference sources & Examples of items \\
\hline The disputed amount $\mathrm{t}^{\mathrm{a}}$ & $\begin{array}{l}\text { Marzouk and Moamen (2009); Marzouk et al. } \\
\text { (2011); Zhang et al. (2016) }\end{array}$ & $\begin{array}{l}\text { "The approximate ratio of the disputed claim amount to the total contract amount was (considering } \\
\text { the claim for additional payment and extension of time)" }\end{array}$ \\
\hline Procedural fairness & Liu et al. (2012); Lu et al. (2017) & "The owner took our concern and feedback during the process of handling the claim" \\
\hline Time pressure & Van Kleef et al. (2004) & "Our party experienced considerable time pressure" \\
\hline Favourability of evidence & Lu and Liu (2014) & "Our party's collected evidence in support of the claim was very favourable" \\
\hline Trust & Jiang et al. (2013); Zhang et al. (2016) & "Our party believed that the owner was trustworthy" \\
\hline $\begin{array}{l}\text { Occurrence time of the } \\
\text { dispute }^{\mathrm{a}}\end{array}$ & Lumineau and Oxley (2012) & "Until the dispute happened, what percentage of the total contract duration had been completed?" \\
\hline Other ongoing project(s) ${ }^{\mathrm{a}}$ & Marzouk and Moamen (2009) & "Was there other ongoing project(s) with this owner during the process of dispute resolution?" \\
\hline Future cooperation & Lui and Ngo (2012); Poppo and Zhou (2014) & "Our party expected to work with the owner on future projects" \\
\hline Reputation & Carson et al. (2006) & "It was easy for outsiders to learn about how our party behaved in the previous projects" \\
\hline The owner's lock-in \& The & Poppo et al. (2008) & "The losses of terminating the project midway would have been prohibitive for the owner"; \\
\hline contractor's lock-in & & "The losses of withdrawing from the project midway would have been prohibitive for our party" \\
\hline $\begin{array}{l}\text { The cost of pursuing the } \\
\text { disputed claim }^{\mathrm{a}}\end{array}$ & Gebken (2006) & $\begin{array}{l}\text { "During the process of dispute resolution, your party believed that the cost of insisting the disputed } \\
\text { amount (such as expenses for dispute handling personnel, lawyers' fees, and arbitration/court fees), }\end{array}$ \\
\hline & & compared with the disputed amount, would be" \\
\hline Cash flow status & Marzouk et al. (2011); Park et al. (2005) & "Our party was in desperate need of cash to support daily construction activities" \\
\hline Contractual approach & $\begin{array}{l}\text { Cheung and Chow (2011); Lin and Germain } \\
\text { (1998); Wang et al. (2005) }\end{array}$ & $\begin{array}{l}\text { "Our party argued strongly on just grounds and used the contract as a tool to get the owner to agree } \\
\text { to our position" }\end{array}$ \\
\hline Relational approach & Cheung et al. (2006); Lu, W. et al. (2015) & $\begin{array}{l}\text { "Our party tried to satisfy the expectations of the owner" (obliging) } \\
\text { "Our party used give and take so that a compromise could be reached" (compromising) }\end{array}$ \\
\hline
\end{tabular}

${ }^{\mathrm{a}}$ Measured by one single indicator. 
Table 3. Sample characteristics

\begin{tabular}{|c|c|c|c|}
\hline & Characteristics & Number & Percentage \\
\hline \multirow[t]{6}{*}{ Professional qualifications } & Project manager & 103 & 41.5 \\
\hline & Contract administrator & 70 & 28.2 \\
\hline & Cost administrator & 22 & 8.9 \\
\hline & Administrator of contract and cost & 12 & 4.9 \\
\hline & Others (e.g., chief engineers and senior managers of & 41 & 16.5 \\
\hline & companies) & & \\
\hline \multirow[t]{4}{*}{ Years of working experience } & $<5$ years & 42 & 16.9 \\
\hline & $5-9$ years & 67 & 27.0 \\
\hline & $10-19$ years & 89 & 35.9 \\
\hline & $\geq 20$ years & 50 & 20.2 \\
\hline \multirow[t]{4}{*}{ Project types } & Buildings & 105 & 42.3 \\
\hline & Transportation & 56 & 22.6 \\
\hline & Industrial & 46 & 18.6 \\
\hline & Others (e.g., petroleum projects and water projects) & 41 & 16.5 \\
\hline \multirow[t]{3}{*}{ Contract types - the scope of work } & DBB & 89 & 35.9 \\
\hline & Project general contracting (e.g., DB and EPC) & 156 & 62.9 \\
\hline & Others (e.g., mixed) & 3 & 1.2 \\
\hline \multirow[t]{4}{*}{ Contract types - fee arrangement } & Unit Price & 76 & 30.7 \\
\hline & Lump Sum & 162 & 65.3 \\
\hline & Cost Plus Fee & 4 & 1.6 \\
\hline & Others (e.g., mixed) & 6 & 2.4 \\
\hline \multirow[t]{2}{*}{ Project locations } & China & 66 & 26.6 \\
\hline & Outside China & 182 & 73.4 \\
\hline \multirow[t]{2}{*}{ Whether or not from the same country } & Yes & 67 & 27.0 \\
\hline & No & 181 & 73.0 \\
\hline \multirow[t]{2}{*}{ Enterprise types of contractors } & State-owned enterprise & 228 & 91.9 \\
\hline & Private enterprise & 20 & 8.1 \\
\hline \multirow[t]{4}{*}{ Enterprise types of owners } & Government & 111 & 44.8 \\
\hline & State-owned enterprise & 73 & 29.4 \\
\hline & Private enterprise & 56 & 22.6 \\
\hline & Others (e.g., foreign enterprise) & 8 & 3.2 \\
\hline
\end{tabular}




\section{To insist or to concede? Contractors' behavioural strategies when handling disputed claims}

\section{Supplemental Data}

Tables in the supplemental data show the detailed results of descriptive statistics and the evaluation of measurement models and the structural model.

Table S1. Descriptive statistics and correlations

\begin{tabular}{|c|c|c|c|c|c|c|c|c|c|c|c|c|c|c|c|c|c|}
\hline \multirow{2}{*}{ Variables } & \multirow{2}{*}{ Means } & \multirow{2}{*}{$\begin{array}{l}\text { Standard } \\
\text { deviations }\end{array}$} & \multicolumn{15}{|c|}{ Pearson correlation matrix } \\
\hline & & & 1 & 2 & 3 & 4 & 5 & 6 & 7 & 8 & 9 & 10 & 11 & 12 & 13 & 14 & 15 \\
\hline 1. The disputed amount & 4.069 & 1.414 & & & & & & & & & & & & & & & \\
\hline 2. Procedural Fairness & 4.774 & 1.134 & -.028 & & & & & & & & & & & & & & \\
\hline 3. Time pressure & 5.062 & 1.305 & .087 & -.047 & & & & & & & & & & & & & \\
\hline 4. Favourability of evidence & 5.315 & 1.256 & .070 & .126 & .191 & & & & & & & & & & & & \\
\hline 5. Trust & 4.512 & 1.114 & -.037 & .486 & -.025 & .048 & & & & & & & & & & & \\
\hline $\begin{array}{l}\text { 6. Occurrence time of the } \\
\text { dispute }\end{array}$ & 3.649 & 1.347 & .047 & .049 & .029 & -.125 & -.046 & & & & & & & & & & \\
\hline 7. Other ongoing project(s) & 1.440 & .497 & .066 & -.158 & -.015 & -.125 & -.105 & -.035 & & & & & & & & & \\
\hline 8. Future cooperation & 5.567 & 1.141 & -.055 & .208 & .000 & .109 & .308 & -.013 & -.241 & & & & & & & & \\
\hline 9. Reputation & 5.730 & .814 & .034 & .260 & .338 & .167 & .262 & -.009 & -.165 & .337 & & & & & & & \\
\hline 10. Lock-in asymmetry & -.254 & 1.473 & .039 & .254 & -.053 & -.023 & .144 & .003 & -.021 & -.034 & -.006 & & & & & & \\
\hline 11. The cost of pursuing the & 3.206 & 1.354 & .255 & -.123 & .133 & -.011 & -.127 & .115 & .046 & -.122 & .075 & -.110 & & & & & \\
\hline
\end{tabular}


disputed claim

12. Cash flow

13. Contractual approach

\begin{tabular}{|r}
4.278 \\
4.929 \\
\hline pproach \\
4.234 \\
\hline
\end{tabular}

1.587

$.184 \quad-.107$

.343

0.062

$-.007$

1.288

$.124 \quad .020$

.150

.069

$-.007 \quad-.091$

.133

$-.240$

.008

$-.128$

.152

14. Relational approach

regarding obliging

1.414

$-.139$

$-.096 \quad .24$

$-.104$

.094

$-.058$

$.058 \quad-.027$

$.090 \quad .078 \quad-.098$

.006

15. Relational approach

5.763

.986

$\begin{array}{lllll}-.179 & .033 & .189 & .069 & .069\end{array}$

.007

$.173 \quad .165$

$\begin{array}{llll}-.072 & .0718 & -.056 & -.055\end{array}$

regarding compromising

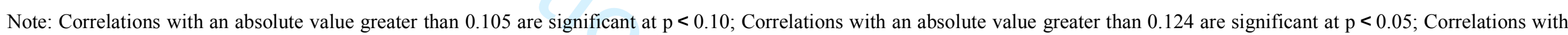
an absolute value greater than 0.164 are significant at $\mathrm{p}<0.01$. 
Table S2. Results of internal consistency reliability

\begin{tabular}{|c|c|c|c|}
\hline & Constructs & Cronbach's alpha & Composite reliability \\
\hline \multirow[t]{10}{*}{ Drivers } & Procedural fairness & 0.836 & 0.897 \\
\hline & Time pressure & 0.885 & 0.929 \\
\hline & Favourability of evidence & 0.948 & 0.967 \\
\hline & Trust & 0.860 & 0.886 \\
\hline & Future cooperation & 0.877 & 0.924 \\
\hline & Reputation & 0.632 & 0.798 \\
\hline & The owner's lock-in (switching to another contractor) & 0.891 & / \\
\hline & The owner's lock-in (terminating the project) & 0.929 & / \\
\hline & The contractor's lock-in & 0.917 & / \\
\hline & Cash flow status & 0.935 & 0.955 \\
\hline \multirow{3}{*}{$\begin{array}{l}\text { Behavioural } \\
\text { strategies }\end{array}$} & Contractual approach & 0.770 & 0.866 \\
\hline & Relational approach regarding obliging & 0.849 & 0.908 \\
\hline & Relational approach regarding compromising & 0.829 & 0.897 \\
\hline
\end{tabular}

Note: The owner's lock-in and the contractor's lock-in are not directly connected with others in the structural model, and thus the composite reliability is not accessible by SmartPLS.

Table S3. Results of convergent validity

\begin{tabular}{llll}
\hline & & Convergent validity \\
\cline { 2 - 3 } Constructs & Indicators & Outer loadings & AVE \\
\hline Procedural fairness (PF) & & 0.832 & 0.744 \\
Time pressure (TP) & PF_1 & 0.837 & 0.916 \\
Favourability of evidence (FE) & PF_2 & 0.901 & 0.813 \\
& PF_3 & 0.911 & 0.893 \\
\hline Trust (TR) & TP_1 & 0.952 \\
\hline
\end{tabular}




\begin{tabular}{|c|c|c|c|}
\hline \multirow[t]{3}{*}{ Future cooperation (FC) } & FC_1 & 0.875 & \multirow{3}{*}{0.802} \\
\hline & FC_2 & 0.929 & \\
\hline & FC_3 & 0.882 & \\
\hline \multirow[t]{3}{*}{ Reputation (RP) } & RP_1 & 0.793 & \multirow{3}{*}{0.578} \\
\hline & RP_2 & 0.904 & \\
\hline & RP_3 & 0.537 & \\
\hline \multirow[t]{3}{*}{ Cash flow status (CF) } & CF_1 & 0.912 & \multirow{3}{*}{0.875} \\
\hline & CF_2 & 0.944 & \\
\hline & CF_3 & 0.950 & \\
\hline \multirow[t]{3}{*}{ Contractual approach (Contractual) } & Contractual_1 & 0.872 & \multirow{3}{*}{0.683} \\
\hline & Contractual_2 & 0.864 & \\
\hline & Contractual_3 & 0.737 & \\
\hline \multirow[t]{3}{*}{ Relational approach regarding obliging (Obliging) } & Obliging_1 & 0.891 & \multirow{3}{*}{0.768} \\
\hline & Obliging_2 & 0.845 & \\
\hline & Obliging_3 & 0.892 & \\
\hline \multirow{4}{*}{$\begin{array}{l}\text { Relational approach regarding compromising } \\
\text { (Compromising) }\end{array}$} & Compromising 1 & 0.860 & \multirow{4}{*}{0.745} \\
\hline & & & \\
\hline & Compromising_2 & 0.869 & \\
\hline & Compromising_3 & 0.860 & \\
\hline
\end{tabular}


Table S4. Indicators' cross-loadings and outer loadings

\begin{tabular}{|c|c|c|c|c|c|c|c|c|c|c|c|c|c|c|c|}
\hline Indicators & DA & PF & $\mathrm{TP}$ & $\mathrm{FE}$ & $\mathrm{TR}$ & OT & OP & FC & $\mathrm{RP}$ & LA & $\mathrm{CPC}$ & $\mathrm{CF}$ & Contractual & Obliging & Compromising \\
\hline DA & 1.000 & -0.034 & 0.084 & 0.071 & -0.055 & 0.047 & 0.066 & -0.060 & 0.024 & 0.039 & 0.255 & 0.188 & 0.121 & -0.138 & -0.177 \\
\hline PF_1 & -0.051 & 0.832 & -0.030 & 0.162 & 0.439 & -0.017 & -0.115 & 0.218 & 0.240 & 0.188 & -0.115 & -0.074 & 0.002 & -0.044 & 0.085 \\
\hline PF_2 & 0.022 & 0.837 & -0.039 & 0.050 & 0.381 & 0.038 & -0.139 & 0.153 & 0.156 & 0.230 & -0.115 & -0.006 & 0.007 & -0.092 & -0.044 \\
\hline PF_3 & -0.047 & 0.916 & -0.045 & 0.117 & 0.422 & 0.110 & -0.160 & 0.174 & 0.243 & 0.246 & -0.091 & -0.203 & 0.045 & -0.106 & 0.047 \\
\hline TP_1 & 0.158 & -0.064 & 0.901 & 0.185 & -0.094 & 0.075 & 0.024 & 0.014 & 0.293 & -0.071 & 0.124 & 0.353 & 0.190 & 0.196 & 0.150 \\
\hline TP_2 & 0.058 & -0.086 & 0.911 & 0.214 & 0.002 & 0.015 & -0.062 & -0.011 & 0.259 & -0.055 & 0.128 & 0.281 & 0.074 & 0.267 & 0.140 \\
\hline TP_3 & 0.018 & 0.020 & 0.893 & 0.119 & 0.022 & -0.014 & -0.003 & 0.001 & 0.329 & -0.017 & 0.107 & 0.236 & 0.136 & 0.220 & 0.227 \\
\hline FE_1 & 0.056 & 0.099 & 0.162 & 0.952 & -0.002 & -0.132 & -0.100 & 0.095 & 0.140 & -0.036 & -0.038 & -0.086 & 0.236 & -0.131 & 0.066 \\
\hline FE_2 & 0.101 & 0.107 & 0.203 & 0.959 & -0.018 & -0.099 & -0.127 & 0.081 & 0.131 & -0.011 & 0.011 & -0.050 & 0.272 & -0.076 & 0.064 \\
\hline FE_3 & 0.043 & 0.158 & 0.174 & 0.946 & 0.013 & -0.126 & -0.129 & 0.137 & 0.177 & -0.019 & -0.005 & -0.055 & 0.253 & -0.082 & 0.072 \\
\hline TR_1 & -0.021 & 0.391 & -0.032 & 0.146 & 0.680 & -0.074 & -0.055 & 0.264 & 0.135 & 0.073 & -0.123 & 0.009 & -0.050 & 0.029 & 0.004 \\
\hline TR_2 & 0.012 & 0.384 & -0.001 & 0.105 & 0.691 & -0.094 & -0.087 & 0.279 & 0.222 & 0.011 & -0.112 & 0.016 & -0.067 & 0.042 & 0.018 \\
\hline TR_3 & -0.011 & 0.433 & -0.015 & -0.031 & 0.923 & -0.038 & -0.082 & 0.222 & 0.159 & 0.190 & -0.094 & -0.010 & -0.147 & 0.096 & 0.039 \\
\hline TR_4 & -0.100 & 0.415 & -0.030 & -0.048 & 0.931 & 0.046 & -0.125 & 0.282 & 0.202 & 0.197 & -0.100 & -0.054 & -0.127 & 0.139 & 0.158 \\
\hline OT & 0.047 & 0.065 & 0.027 & -0.125 & -0.014 & 1.000 & -0.035 & -0.013 & -0.001 & 0.003 & 0.115 & -0.088 & -0.058 & 0.147 & 0.021 \\
\hline OP & 0.066 & -0.163 & -0.014 & -0.125 & -0.114 & -0.035 & 1.000 & -0.241 & -0.149 & -0.021 & 0.046 & 0.129 & 0.058 & 0.006 & 0.028 \\
\hline FC_1 & -0.073 & 0.209 & -0.001 & 0.079 & 0.270 & -0.037 & -0.194 & 0.875 & 0.309 & -0.051 & -0.142 & -0.214 & -0.034 & 0.129 & 0.238 \\
\hline FC_2 & -0.092 & 0.190 & 0.016 & 0.110 & 0.310 & -0.008 & -0.225 & 0.929 & 0.353 & -0.052 & -0.150 & -0.226 & -0.018 & 0.188 & 0.294 \\
\hline FC_3 & 0.013 & 0.156 & -0.015 & 0.101 & 0.217 & -0.007 & -0.228 & 0.882 & 0.240 & 0.009 & -0.041 & -0.226 & -0.027 & 0.153 & 0.230 \\
\hline
\end{tabular}




\begin{tabular}{|c|c|c|c|c|c|c|c|c|c|c|c|c|c|c|c|}
\hline $\mathrm{RP} \_1$ & 0.085 & 0.253 & 0.275 & 0.136 & 0.235 & 0.049 & -0.167 & 0.314 & 0.793 & 0.025 & 0.040 & 0.011 & 0.045 & 0.138 & 0.205 \\
\hline RP_2 & -0.015 & 0.182 & 0.259 & 0.117 & 0.103 & -0.005 & -0.090 & 0.273 & 0.904 & 0.035 & 0.032 & -0.080 & 0.141 & 0.071 & 0.380 \\
\hline $\mathrm{RP} \_3$ & 0.004 & 0.162 & 0.238 & 0.123 & 0.222 & -0.058 & -0.114 & 0.197 & 0.537 & -0.061 & 0.090 & 0.035 & 0.039 & 0.164 & 0.126 \\
\hline LA & 0.039 & 0.259 & -0.052 & -0.023 & 0.180 & 0.003 & -0.021 & -0.037 & 0.014 & 1.000 & -0.110 & -0.136 & 0.084 & -0.071 & 0.003 \\
\hline $\mathrm{CPC}$ & 0.255 & -0.119 & 0.132 & -0.011 & -0.117 & 0.115 & 0.046 & -0.127 & 0.059 & -0.110 & 1.000 & 0.154 & -0.104 & 0.121 & -0.128 \\
\hline $\mathrm{CF}_{-} 1$ & 0.152 & -0.124 & 0.380 & -0.050 & -0.009 & -0.097 & 0.132 & -0.198 & 0.021 & -0.087 & 0.130 & 0.912 & -0.011 & -0.007 & -0.070 \\
\hline CF_2 & 0.185 & -0.147 & 0.334 & -0.044 & -0.009 & -0.081 & 0.136 & -0.233 & -0.010 & -0.136 & 0.154 & 0.944 & -0.016 & -0.064 & -0.096 \\
\hline $\mathrm{CF} \_3$ & 0.181 & -0.111 & 0.246 & -0.081 & -0.045 & -0.078 & 0.108 & -0.247 & -0.071 & -0.137 & 0.143 & 0.950 & -0.016 & -0.092 & -0.136 \\
\hline Contractual_1 & 0.087 & 0.018 & 0.110 & 0.282 & -0.128 & -0.053 & 0.054 & -0.041 & 0.113 & 0.113 & -0.134 & -0.075 & 0.872 & -0.119 & 0.153 \\
\hline Contractual_2 & 0.135 & -0.006 & 0.132 & 0.160 & -0.115 & -0.029 & 0.096 & -0.038 & 0.053 & 0.011 & -0.026 & -0.015 & 0.864 & -0.054 & 0.170 \\
\hline Contractual_3 & 0.088 & 0.054 & 0.133 & 0.194 & -0.087 & -0.060 & -0.005 & 0.015 & 0.108 & 0.063 & -0.075 & 0.108 & 0.737 & 0.051 & 0.286 \\
\hline Obliging_1 & -0.136 & -0.115 & 0.184 & -0.141 & 0.103 & 0.116 & 0.011 & 0.141 & 0.072 & -0.052 & 0.069 & -0.032 & -0.091 & 0.891 & 0.165 \\
\hline Obliging _2 & -0.114 & -0.016 & 0.257 & -0.048 & 0.104 & 0.146 & 0.001 & 0.207 & 0.213 & -0.031 & 0.140 & -0.077 & -0.015 & 0.845 & 0.263 \\
\hline Obliging _3 & -0.115 & -0.131 & 0.217 & -0.079 & 0.099 & 0.124 & 0.006 & 0.115 & 0.078 & -0.104 & 0.105 & -0.075 & -0.058 & 0.892 & 0.198 \\
\hline Compromising_1 & -0.193 & 0.034 & 0.119 & 0.019 & 0.122 & 0.014 & 0.028 & 0.254 & 0.267 & 0.055 & -0.155 & -0.116 & 0.169 & 0.253 & 0.860 \\
\hline Compromising_2 & -0.108 & 0.141 & 0.162 & 0.124 & 0.117 & 0.033 & -0.013 & 0.233 & 0.358 & 0.045 & -0.114 & -0.085 & 0.240 & 0.090 & 0.869 \\
\hline Compromising_3 & -0.156 & -0.070 & 0.217 & 0.042 & 0.020 & 0.007 & 0.057 & 0.256 & 0.270 & -0.087 & -0.064 & -0.102 & 0.207 & 0.273 & 0.860 \\
\hline
\end{tabular}

Note: (1) DA = the disputed amount; PF = procedural fairness; TP = time pressure; FE = favourability of evidence; TR = trust; OT = occurrence time of the dispute; OP = other ongoing project(s); FC = future cooperation; RP = reputation; LA = lock-in asymmetry; $\mathrm{CPC}=$ the cost of pursuing the disputed claim; $\mathrm{CF}=$ cash flow status; Contractual $=$ contractual approach; Obliging $=$ relational approach regarding obliging; Compromising = relational approach regarding compromising.

(2) Numbers in bold are indicators' outer loadings on their associated constructs. 
Table S5. Results of Fornell-Larcker criterion

\begin{tabular}{|c|c|c|c|c|c|c|c|c|c|c|c|c|c|c|c|}
\hline Constructs & DA & $\mathrm{PF}$ & $\mathrm{TP}$ & $\mathrm{FE}$ & $\mathrm{TR}$ & OT & OP & $\mathrm{FC}$ & $\mathrm{RP}$ & LA & $\mathrm{CPC}$ & $\mathrm{CF}$ & Contractual & Obliging & Compromising \\
\hline $\mathrm{DA}$ & 1.000 & & & & & & & & & & & & & & \\
\hline PF & -0.034 & 0.863 & & & & & & & & & & & & & \\
\hline $\mathrm{TP}$ & 0.084 & -0.045 & 0.902 & & & & & & & & & & & & \\
\hline FE & 0.071 & 0.127 & 0.189 & 0.952 & & & & & & & & & & & \\
\hline TR & -0.055 & 0.476 & -0.024 & -0.003 & 0.815 & & & & & & & & & & \\
\hline OT & 0.047 & 0.065 & 0.027 & -0.125 & -0.014 & 1.000 & & & & & & & & & \\
\hline OP & 0.066 & -0.163 & -0.014 & -0.125 & -0.114 & -0.035 & 1.000 & & & & & & & & \\
\hline $\mathrm{FC}$ & -0.060 & 0.206 & 0.001 & 0.109 & 0.300 & -0.013 & -0.241 & 0.896 & & & & & & & \\
\hline $\mathrm{RP}$ & 0.024 & 0.251 & 0.327 & 0.156 & 0.212 & -0.001 & -0.149 & 0.339 & 0.760 & & & & & & \\
\hline LA & 0.039 & 0.259 & -0.052 & -0.023 & 0.180 & 0.003 & -0.021 & -0.037 & 0.014 & 1.000 & & & & & \\
\hline $\mathrm{CPC}$ & 0.255 & -0.119 & 0.132 & -0.011 & -0.117 & 0.115 & 0.046 & -0.127 & 0.059 & -0.110 & 1.000 & & & & \\
\hline $\mathrm{CF}$ & 0.188 & -0.134 & 0.319 & -0.067 & -0.028 & -0.088 & 0.129 & -0.247 & -0.035 & -0.136 & 0.154 & 0.935 & & & \\
\hline Contractual & 0.121 & 0.026 & 0.148 & 0.267 & -0.135 & -0.058 & 0.058 & -0.028 & 0.114 & 0.084 & -0.104 & -0.005 & 0.827 & & \\
\hline Obliging & -0.138 & -0.098 & 0.252 & -0.101 & 0.116 & 0.147 & 0.006 & 0.177 & 0.140 & -0.071 & 0.121 & -0.071 & -0.061 & 0.876 & \\
\hline Compromising & -0.177 & 0.038 & 0.193 & 0.071 & 0.098 & 0.021 & 0.028 & 0.287 & 0.345 & 0.003 & -0.128 & -0.117 & 0.238 & 0.240 & 0.863 \\
\hline
\end{tabular}

Note: $(1) \mathrm{DA}=$ the disputed amount; $\mathrm{PF}=$ procedural fairness; $\mathrm{TP}=$ time pressure; $\mathrm{FE}=$ favourability of evidence; $\mathrm{TR}=$ trust; $\mathrm{OT}=\mathrm{occurrence}$ time of the dispute; OP = other ongoing project(s); $\mathrm{FC}=$ future cooperation; $\mathrm{RP}=$ reputation; $\mathrm{LA}=$ lock-in asymmetry; $\mathrm{CPC}=$ the cost of pursuing the disputed claim; $\mathrm{CF}=$ cash flow status; Contractual $=$ contractual approach; Obliging = relational approach regarding obliging; Compromising = relational approach regarding compromising.

(2) The values on the diagonal are the square root of reflective constructs' AVE values. The values in the off-diagonal position are the correlations between the constructs. 
Table S6. The HTMT values for all pairs of constructs

\begin{tabular}{|c|c|c|c|c|c|c|c|c|c|c|c|c|c|c|c|}
\hline Constructs & DA & PF & $\mathrm{TP}$ & $\mathrm{FE}$ & $\mathrm{TR}$ & OT & $\mathrm{OP}$ & $\mathrm{FC}$ & $\mathrm{RP}$ & LA & $\mathrm{CPC}$ & $\mathrm{CF}$ & Contractual & Obliging & Compromising \\
\hline \multicolumn{16}{|l|}{ DA } \\
\hline PF & 0.050 & & & & & & & & & & & & & & \\
\hline TP & 0.092 & 0.071 & & & & & & & & & & & & & \\
\hline FE & 0.072 & 0.142 & 0.209 & & & & & & & & & & & & \\
\hline TR & 0.046 & 0.573 & 0.049 & 0.109 & & & & & & & & & & & \\
\hline OT & 0.047 & 0.069 & 0.041 & 0.128 & 0.081 & & & & & & & & & & \\
\hline $\mathrm{OP}$ & 0.066 & 0.174 & 0.035 & 0.128 & 0.112 & 0.035 & & & & & & & & & \\
\hline $\mathrm{FC}$ & 0.071 & 0.244 & 0.021 & 0.119 & 0.356 & 0.021 & 0.257 & & & & & & & & \\
\hline $\mathrm{RP}$ & 0.057 & 0.357 & 0.451 & 0.213 & 0.341 & 0.061 & 0.205 & 0.457 & & & & & & & \\
\hline LA & 0.039 & 0.279 & 0.056 & 0.024 & 0.152 & 0.003 & 0.021 & 0.044 & 0.067 & & & & & & \\
\hline $\mathrm{CPC}$ & 0.255 & 0.135 & 0.141 & 0.020 & 0.137 & 0.115 & 0.046 & 0.132 & 0.089 & 0.110 & & & & & \\
\hline $\mathrm{CF}$ & 0.190 & 0.131 & 0.377 & 0.066 & 0.035 & 0.094 & 0.138 & 0.265 & 0.094 & 0.132 & 0.157 & & & & \\
\hline Contractual & 0.142 & 0.044 & 0.183 & 0.299 & 0.141 & 0.065 & 0.071 & 0.050 & 0.150 & 0.086 & 0.108 & 0.099 & & & \\
\hline Obliging & 0.151 & 0.120 & 0.289 & 0.114 & 0.107 & 0.159 & 0.007 & 0.201 & 0.220 & 0.077 & 0.130 & 0.069 & 0.112 & & \\
\hline Compromising & 0.194 & 0.113 & 0.222 & 0.081 & 0.089 & 0.023 & 0.042 & 0.333 & 0.432 & 0.079 & 0.141 & 0.121 & 0.308 & 0.281 & \\
\hline
\end{tabular}

Note: $\mathrm{DA}=$ the disputed amount $\mathrm{PF}=$ procedural fairness; $\mathrm{TP}=$ time pressure; $\mathrm{FE}=$ favourability of evidence; $\mathrm{TR}=$ trust; $\mathrm{OT}=\mathrm{occurrence}$ time of the dispute; $\mathrm{OP}=$ other ongoing project(s); $\mathrm{FC}=$ future cooperation; $\mathrm{RP}=$ reputation; $\mathrm{LA}=$ lock-in asymmetry; $\mathrm{CPC}=$ the cost of pursuing the disputed claim; $\mathrm{CF}=$ cash flow status; $\mathrm{Contractual}=$ contractual approach; Obliging = relational approach regarding obliging; Compromising = relational approach regarding compromising. 
Table S7. Confidence intervals bias corrected for HTMT

\begin{tabular}{|c|c|c|c|c|c|}
\hline Pairs of constructs & $\begin{array}{l}\text { Original } \\
\text { sample }\end{array}$ & $\begin{array}{l}\text { Sample } \\
\text { mean }\end{array}$ & $5.0 \%$ & $95.0 \%$ & $\begin{array}{l}\text { Confidence interva } \\
\text { does not include } 1\end{array}$ \\
\hline $\mathrm{CPC}->\mathrm{CF}$ & 0.157 & 0.159 & 0.044 & 0.274 & Yes \\
\hline Compromising $->\mathrm{CF}$ & 0.121 & 0.132 & 0.049 & 0.228 & Yes \\
\hline Compromising $->\mathrm{CPC}$ & 0.141 & 0.148 & 0.046 & 0.260 & Yes \\
\hline Contractual $->\mathrm{CF}$ & 0.099 & 0.123 & 0.037 & 0.135 & Yes \\
\hline Contractual -> CPC & 0.108 & 0.127 & 0.044 & 0.215 & Yes \\
\hline Contractual -> COM & 0.308 & 0.308 & 0.178 & 0.447 & Yes \\
\hline $\mathrm{DA}->\mathrm{CF}$ & 0.190 & 0.189 & 0.068 & 0.305 & Yes \\
\hline $\mathrm{DA}->\mathrm{CPC}$ & 0.255 & 0.254 & 0.148 & 0.360 & Yes \\
\hline DA -> Compromising & 0.194 & 0.195 & 0.074 & 0.317 & Yes \\
\hline DA -> Contractual & 0.142 & 0.148 & 0.042 & 0.259 & Yes \\
\hline $\mathrm{FC}->\mathrm{CF}$ & 0.265 & 0.264 & 0.154 & 0.375 & Yes \\
\hline $\mathrm{FC}->\mathrm{CPC}$ & 0.132 & 0.141 & 0.052 & 0.240 & Yes \\
\hline FC $->$ Compromising & 0.333 & 0.334 & 0.212 & 0.449 & Yes \\
\hline FC $->$ Contractual & 0.050 & 0.095 & 0.020 & 0.056 & Yes \\
\hline $\mathrm{FC}->\mathrm{DA}$ & 0.071 & 0.091 & 0.021 & 0.127 & Yes \\
\hline $\mathrm{FE}->\mathrm{CF}$ & 0.066 & 0.089 & 0.025 & 0.164 & Yes \\
\hline $\mathrm{FE}->\mathrm{CPC}$ & 0.020 & 0.059 & 0.001 & 0.021 & Yes \\
\hline FE -> Compromising & 0.081 & 0.111 & 0.032 & 0.154 & Yes \\
\hline FE -> Contractual & 0.299 & 0.299 & 0.161 & 0.441 & Yes \\
\hline $\mathrm{FE}->\mathrm{DA}$ & 0.072 & 0.087 & 0.023 & 0.172 & Yes \\
\hline $\mathrm{FE}->\mathrm{FC}$ & 0.119 & 0.127 & 0.041 & 0.245 & Yes \\
\hline $\mathrm{LA}->\mathrm{CF}$ & 0.132 & 0.138 & 0.032 & 0.250 & Yes \\
\hline $\mathrm{LA}->\mathrm{CPC}$ & 0.110 & 0.113 & 0.014 & 0.217 & Yes \\
\hline LA -> Compromising & 0.079 & 0.098 & 0.021 & 0.120 & Yes \\
\hline LA -> Contractual & 0.086 & 0.115 & 0.025 & 0.149 & Yes \\
\hline LA -> DA & 0.039 & 0.066 & 0.001 & 0.110 & Yes \\
\hline LA $->$ FC & 0.044 & 0.074 & 0.007 & 0.074 & Yes \\
\hline LA $->$ FE & 0.024 & 0.065 & 0.003 & 0.038 & Yes \\
\hline $\mathrm{OP}->\mathrm{CF}$ & 0.138 & 0.138 & 0.038 & 0.246 & Yes \\
\hline
\end{tabular}




\begin{tabular}{|c|c|c|c|c|c|}
\hline $\mathrm{OP}->\mathrm{CPC}$ & 0.046 & 0.062 & 0.002 & 0.129 & Yes \\
\hline OP -> Compromising & 0.042 & 0.076 & 0.003 & 0.059 & Yes \\
\hline OP -> Contractual & 0.071 & 0.101 & 0.015 & 0.128 & Yes \\
\hline $\mathrm{OP}->\mathrm{DA}$ & 0.066 & 0.076 & 0.005 & 0.161 & Yes \\
\hline $\mathrm{OP}->\mathrm{FC}$ & 0.257 & 0.257 & 0.143 & 0.355 & Yes \\
\hline $\mathrm{OP}->\mathrm{FE}$ & 0.128 & 0.130 & 0.032 & 0.235 & Yes \\
\hline OP $->$ LA & 0.021 & 0.054 & 0.000 & 0.059 & Yes \\
\hline $\mathrm{OT}->\mathrm{CF}$ & 0.094 & 0.102 & 0.020 & 0.209 & Yes \\
\hline $\mathrm{OT}->\mathrm{CPC}$ & 0.115 & 0.117 & 0.014 & 0.221 & Yes \\
\hline OT -> Compromising & 0.023 & 0.067 & 0.004 & 0.026 & Yes \\
\hline OT -> Contractual & 0.065 & 0.087 & 0.017 & 0.136 & Yes \\
\hline $\mathrm{OT}->\mathrm{DA}$ & 0.047 & 0.065 & 0.002 & 0.131 & Yes \\
\hline $\mathrm{OT}->\mathrm{FC}$ & 0.021 & 0.065 & 0.003 & 0.025 & Yes \\
\hline $\mathrm{OT}->\mathrm{FE}$ & 0.128 & 0.128 & 0.035 & 0.234 & Yes \\
\hline OT $->$ LA & 0.003 & 0.054 & 0.000 & 0.002 & Yes \\
\hline $\mathrm{OT}->\mathrm{OP}$ & 0.035 & 0.058 & 0.001 & 0.098 & Yes \\
\hline Obliging $->\mathrm{CF}$ & 0.069 & 0.100 & 0.026 & 0.112 & Yes \\
\hline Obliging $->\mathrm{CPC}$ & 0.130 & 0.135 & 0.042 & 0.255 & Yes \\
\hline Obliging $->$ Compromising & 0.281 & 0.292 & 0.172 & 0.390 & Yes \\
\hline Obliging $->$ Contractual & 0.112 & 0.143 & 0.050 & 0.154 & Yes \\
\hline Obliging $->$ DA & 0.151 & 0.152 & 0.046 & 0.265 & Yes \\
\hline Obliging $->$ FC & 0.201 & 0.205 & 0.095 & 0.317 & Yes \\
\hline Obliging $->\mathrm{FE}$ & 0.114 & 0.131 & 0.048 & 0.211 & Yes \\
\hline Obliging $->$ LA & 0.077 & 0.101 & 0.022 & 0.165 & Yes \\
\hline Obliging $->$ OP & 0.007 & 0.063 & 0.001 & 0.001 & Yes \\
\hline Obliging $->$ OT & 0.159 & 0.160 & 0.051 & 0.273 & Yes \\
\hline $\mathrm{PF}->\mathrm{CF}$ & 0.131 & 0.152 & 0.068 & 0.189 & Yes \\
\hline $\mathrm{PF}->\mathrm{CPC}$ & 0.135 & 0.139 & 0.037 & 0.260 & Yes \\
\hline PF -> Compromising & 0.113 & 0.150 & 0.064 & 0.128 & Yes \\
\hline PF $->$ Contractual & 0.044 & 0.107 & 0.020 & 0.036 & Yes \\
\hline $\mathrm{PF}->\mathrm{DA}$ & 0.050 & 0.084 & 0.007 & 0.079 & Yes \\
\hline $\mathrm{PF}->\mathrm{FC}$ & 0.244 & 0.246 & 0.122 & 0.363 & Yes \\
\hline
\end{tabular}




\begin{tabular}{|c|c|c|c|c|c|}
\hline $\mathrm{PF}->\mathrm{FE}$ & 0.142 & 0.157 & 0.060 & 0.261 & Yes \\
\hline $\mathrm{PF}->\mathrm{LA}$ & 0.279 & 0.278 & 0.151 & 0.394 & Yes \\
\hline $\mathrm{PF}->\mathrm{OP}$ & 0.174 & 0.175 & 0.066 & 0.281 & Yes \\
\hline $\mathrm{PF}->\mathrm{OT}$ & 0.069 & 0.095 & 0.019 & 0.106 & Yes \\
\hline PF -> Obliging & 0.120 & 0.148 & 0.056 & 0.218 & Yes \\
\hline $\mathrm{RP}->\mathrm{CF}$ & 0.094 & 0.134 & 0.037 & 0.119 & Yes \\
\hline $\mathrm{RP}->\mathrm{CPC}$ & 0.089 & 0.117 & 0.020 & 0.159 & Yes \\
\hline RP -> Compromising & 0.432 & 0.437 & 0.288 & 0.566 & Yes \\
\hline RP -> Contractual & 0.150 & 0.189 & 0.064 & 0.226 & Yes \\
\hline $\mathrm{RP}->\mathrm{DA}$ & 0.057 & 0.111 & 0.006 & 0.070 & Yes \\
\hline $\mathrm{RP}->\mathrm{FC}$ & 0.457 & 0.457 & 0.341 & 0.572 & Yes \\
\hline $\mathrm{RP}->\mathrm{FE}$ & 0.213 & 0.220 & 0.099 & 0.345 & Yes \\
\hline $\mathrm{RP}->\mathrm{LA}$ & 0.067 & 0.114 & 0.010 & 0.105 & Yes \\
\hline $\mathrm{RP}->\mathrm{OP}$ & 0.205 & 0.210 & 0.095 & 0.329 & Yes \\
\hline $\mathrm{RP}->\mathrm{OT}$ & 0.061 & 0.104 & 0.003 & 0.088 & Yes \\
\hline RP -> Obliging & 0.220 & 0.245 & 0.117 & 0.321 & Yes \\
\hline $\mathrm{RP}->\mathrm{PF}$ & 0.357 & 0.360 & 0.215 & 0.501 & Yes \\
\hline $\mathrm{TP}->\mathrm{CF}$ & 0.377 & 0.376 & 0.243 & 0.494 & Yes \\
\hline $\mathrm{TP}->\mathrm{CPC}$ & 0.141 & 0.143 & 0.035 & 0.265 & Yes \\
\hline TP -> Compromising & 0.222 & 0.225 & 0.105 & 0.344 & Yes \\
\hline TP -> Contractual & 0.183 & 0.193 & 0.083 & 0.311 & Yes \\
\hline $\mathrm{TP}->\mathrm{DA}$ & 0.092 & 0.112 & 0.035 & 0.170 & Yes \\
\hline $\mathrm{TP}->\mathrm{FC}$ & 0.021 & 0.073 & 0.014 & 0.014 & Yes \\
\hline $\mathrm{TP}->\mathrm{FE}$ & 0.209 & 0.210 & 0.099 & 0.321 & Yes \\
\hline $\mathrm{TP}->\mathrm{LA}$ & 0.056 & 0.085 & 0.011 & 0.109 & Yes \\
\hline $\mathrm{TP}->\mathrm{OP}$ & 0.035 & 0.070 & 0.001 & 0.043 & Yes \\
\hline $\mathrm{TP}->\mathrm{OT}$ & 0.041 & 0.077 & 0.004 & 0.056 & Yes \\
\hline TP -> Obliging & 0.289 & 0.288 & 0.157 & 0.416 & Yes \\
\hline $\mathrm{TP}->\mathrm{PF}$ & 0.071 & 0.106 & 0.020 & 0.098 & Yes \\
\hline $\mathrm{TP}->\mathrm{RP}$ & 0.451 & 0.453 & 0.326 & 0.574 & Yes \\
\hline $\mathrm{TR}->\mathrm{CF}$ & 0.035 & 0.081 & 0.017 & 0.033 & Yes \\
\hline TR $->\mathrm{CPC}$ & 0.137 & 0.141 & 0.046 & 0.245 & Yes \\
\hline
\end{tabular}




\begin{tabular}{llllll}
\hline TR -> Compromising & 0.089 & 0.133 & 0.040 & 0.104 & Yes \\
TR -> Contractual & 0.141 & 0.159 & 0.066 & 0.226 & Yes \\
TR -> DA & 0.046 & 0.087 & 0.008 & 0.058 & Yes \\
TR -> FC & 0.356 & 0.356 & 0.221 & 0.480 & Yes \\
TR -> FE & 0.109 & 0.129 & 0.041 & 0.162 & Yes \\
TR -> LA & 0.152 & 0.167 & 0.063 & 0.234 & Yes \\
TR -> OP & 0.112 & 0.121 & 0.039 & 0.216 & Yes \\
TR -> OT & 0.081 & 0.098 & 0.027 & 0.137 & Yes \\
TR -> Obliging & 0.107 & 0.140 & 0.045 & 0.191 & Yes \\
TR -> PF & 0.573 & 0.573 & 0.461 & 0.667 & Yes \\
TR -> RP & 0.341 & 0.349 & 0.220 & 0.458 & Yes \\
TR -> TP & 0.049 & 0.099 & 0.032 & 0.044 & Yes \\
\hline
\end{tabular}

Note: $\mathrm{DA}=$ the disputed amount $\mathrm{PF}=$ procedural fairness; $\mathrm{TP}=$ time pressure $; \mathrm{FE}=$ favourability of evidence; $\mathrm{TR}=$ trust; $\mathrm{OT}=$ occurrence time of the dispute; $\mathrm{OP}=$ other ongoing project(s); $\mathrm{FC}=$ future cooperation; $\mathrm{RP}=$ reputation; $\mathrm{LA}=$ lock-in asymmetry; $\mathrm{CPC}=$ the cost of pursuing the disputed claim; $\mathrm{CF}=$ cash flow status; Contractual $=$ contractual approach; Obliging $=$ relational approach regarding obliging; Compromising $=$ relational approach regarding compromising.

Table S8. Significance testing of the structural model path coefficients

\begin{tabular}{lcccc}
\hline \multicolumn{1}{c}{ Relationships } & Path coefficients & p values & $\begin{array}{c}90 \% \text { Confidence } \\
\text { intervals bias } \\
\text { corrected }\end{array}$ & $\begin{array}{c}\text { Confidence } \\
\text { interval does not } \\
\text { include } 0\end{array}$ \\
\hline DA -> Contractual & 0.121 & $0.070^{*}$ & {$[0.010,0.232]$} & Yes \\
DA -> Obliging & -0.157 & $0.012^{* *}$ & {$[-0.264,-0.059]$} & Yes \\
DA -> Compromising & -0.158 & $0.018^{* *}$ & {$[-0.271,-0.052]$} & Yes \\
PF -> Contractual & 0.045 & 0.631 & {$[-0.109,0.197]$} & No \\
PF -> Obliging & -0.189 & $0.040^{* *}$ & {$[-0.324,-0.026]$} & Yes \\
PF -> Compromising & -0.089 & 0.396 & {$[-0.264,0.072]$} & No \\
TP -> Contractual & 0.093 & 0.246 & {$[-0.049,0.216]$} & No \\
TP -> Obliging & 0.306 & $0.000^{* * *}$ & {$[0.188,0.414]$} & Yes \\
TP -> Compromising & 0.153 & $0.044^{* *}$ & {$[0.028,0.277]$} & Yes \\
FE -> Contractual & 0.228 & $0.002^{* * *}$ & {$[0.111,0.350]$} & Yes \\
\hline
\end{tabular}




\begin{tabular}{|c|c|c|c|c|}
\hline FE -> Obliging & -0.130 & $0.038 * *$ & {$[-0.228,-0.020]$} & Yes \\
\hline FE -> Compromising & 0.017 & 0.792 & {$[-0.086,0.123]$} & No \\
\hline TR -> Contractual & -0.183 & $0.011 * *$ & {$[-0.289,-0.056]$} & Yes \\
\hline TR -> Obliging & 0.181 & $0.024 * *$ & {$[0.048,0.305]$} & Yes \\
\hline TR -> Compromising & 0.017 & 0.853 & {$[-0.135,0.161]$} & No \\
\hline OT -> Contractual & -0.025 & 0.641 & {$[-0.108,0.070]$} & No \\
\hline OT -> Obliging & 0.120 & $0.037 * *$ & {$[0.032,0.219]$} & Yes \\
\hline OT $->$ Compromising & 0.044 & 0.460 & {$[-0.050,0.145]$} & No \\
\hline OP $->$ Contractual & 0.084 & 0.168 & {$[-0.016,0.187]$} & No \\
\hline OP -> Obliging & 0.051 & 0.389 & {$[-0.049,0.146]$} & No \\
\hline OP $->$ Compromising & 0.136 & $0.017 * *$ & {$[0.042,0.229]$} & Yes \\
\hline FC -> Contractual & -0.039 & 0.555 & {$[-0.151,0.068]$} & No \\
\hline FC -> Obliging & 0.154 & $0.033 * *$ & {$[0.026,0.268]$} & Yes \\
\hline FC -> Compromising & 0.197 & $0.004 * * *$ & {$[0.085,0.308]$} & Yes \\
\hline RP -> Contractual & 0.106 & 0.226 & {$[-0.041,0.247]$} & No \\
\hline $\mathrm{RP}$-> Obliging & 0.015 & 0.847 & {$[-0.115,0.146]$} & No \\
\hline RP -> Compromising & 0.271 & $0.000 * * *$ & {$[0.150,0.396]$} & Yes \\
\hline LA -> Contractual & 0.089 & 0.186 & {$[-0.023,0.196]$} & No \\
\hline LA -> Obliging & -0.035 & 0.575 & {$[-0.137,0.068]$} & No \\
\hline LA -> Compromising & 0.021 & 0.745 & {$[-0.081,0.132]$} & No \\
\hline CPC -> Contractual & -0.159 & $0.018 * *$ & {$[-0.265,-0.045]$} & Yes \\
\hline CPC $->$ Obliging & 0.140 & $0.035 * *$ & {$[0.037,0.258]$} & Yes \\
\hline CPC -> Compromising & -0.103 & 0.139 & {$[-0.218,0.009]$} & No \\
\hline $\mathrm{CF}->$ Contractual & -0.024 & 0.770 & {$[-0.152,0.118]$} & No \\
\hline $\mathrm{CF}$-> Obliging & -0.151 & $0.043 * *$ & {$[-0.271,-0.025]$} & Yes \\
\hline $\mathrm{CF}$-> Compromising & -0.083 & 0.253 & {$[-0.199,0.039]$} & No \\
\hline
\end{tabular}

Note: (1) $\mathrm{DA}=$ the disputed amount; $\mathrm{PF}=$ procedural fairness; $\mathrm{TP}=$ time pressure; $\mathrm{FE}=$ favourability of evidence; $\mathrm{TR}=$ trust; $\mathrm{OT}=$ occurrence time of the dispute; $\mathrm{OP}=$ other ongoing project(s); $\mathrm{FC}=$ future cooperation; $\mathrm{RP}=$ reputation; $\mathrm{LA}=$ lock-in asymmetry; $\mathrm{CPC}=$ the cost of pursuing the disputed claim; $\mathrm{CF}=$ cash flow status; Contractual $=$ contractual approach; Obliging $=$ relational approach regarding obliging; Compromising $=$ relational approach regarding compromising.

(2) $* \mathrm{p}<0.10 ; * * \mathrm{p}<0.05 ; * * * \mathrm{p}<0.01$. 